\title{
Spatial and Temporal Baseline Information on Marine Megafauna-Data Facilitated by a Wildlife Tour Operator
}

\author{
Marijke Nita de Boer ${ }^{1,2,3 *}$, Duncan Jones ${ }^{2}$, Hannah Jones², Rebecca Knee ${ }^{2}$ \\ ${ }^{1}$ Seven Seas Marine Consultancy, Amsterdam, The Netherlands \\ ${ }^{2}$ Marine Discovery Penzance, Penzance, Cornwall, UK \\ ${ }^{3}$ Wageningen UR, Wageningen Marine Research, Den Helder, The Netherlands \\ Email: *marijkedeboer@sevenseasmarine.nl
}

How to cite this paper: de Boer, M.N., Jones, D., Jones, H. and Knee, R. (2018) Spatial and Temporal Baseline Information on Marine Megafauna-Data Facilitated by a Wildlife Tour Operator. Open Journal of Marine Science, 8, 76-113.

https://doi.org/10.4236/ojms.2018.81005

Received: November 2, 2017

Accepted: January 20, 2018

Published: January 23, 2018

Copyright $\odot 2018$ by authors and Scientific Research Publishing Inc. This work is licensed under the Creative Commons Attribution International License (CC BY 4.0).

http://creativecommons.org/licenses/by/4.0/

\begin{abstract}
The protection of marine megafauna within Europe is rather fragmented. Developing conservation measures for highly mobile species presents definite challenges, particularly due to the many knowledge gaps. Recent studies have shown that these gaps can be filled in by Platforms of Opportunity (PO) which create low-cost approaches. However, the number of wildlife tour operators actively collecting PO data related to distribution and relative abundance of marine fauna remains limited. In this study, we investigated whether effort-corrected data on marine megafauna facilitated by a wildlife tour operator afforded robust long temporal data (2011-2015). Sightings data, collected in the wider Mount's Bay area (southwest Cornwall, UK), along with a GPS application, were collected to accurately record survey effort. In addition, radial sighting distances and detection curves were computed to explore the robustness of the data. Density maps of marine megafauna indicated that encounters occurred throughout the area in all three seasons but the temporal distribution was significantly different with numbers peaking in autumn. Odontocetes were mostly recorded during autumn, basking shark (Cetorhinus maximus) and ocean sunfish (Mola mola) were more abundant during summer and leatherback turtles (Dermochelys coriacea) were recorded occasionally. Our data showed that this shallow coastal environment is particularly important as a nursing area for harbour porpoises (Phocoena phocoena). Risso's dolphins (Grampus griseus) showed a high semi-residency pattern for adults with calves within one core-habitat. As such, the study provides important spatial and temporal baseline data that are essential for the protection of marine megafauna through the development of an ecological network of marine protected areas within UK waters. Although, data facilitated by wildlife
\end{abstract}


operators have certain shortcomings we highlight that the protocols developed here secured efficient and precise data. Such collection protocols can be implemented on a larger scale, ultimately enhancing research monitoring efforts and marine ecosystem management.

\section{Keywords}

Marine Megafauna, Platform of Opportunity, Research monitoring, Cornwall

\section{Introduction}

Large marine megafauna such as marine mammals, seabirds, turtles, large pelagic fish and sharks are important top-predators in marine environments, yet they remain poorly understood. They typically range over vast areas of ocean, but concentrate their activities in smaller, localised regions so-called "hotspots", for periods of time [1]. However, relatively little is known about marine megafauna in these hotspots as these species are generally studied on a largescale during surveys that typically provide a single "snapshot" of their distribution [2]. The coastal waters off Southwest England and those waters extending further offshore are believed to provide important habitats for marine megafauna [3]-[10]. The English Channel is a heavily human impacted marine environment with resources benefiting a variety of industry sectors, particularly those of fisheries [11]. Marine megafauna are much exposed within this busy marine channel and are likely to be at a higher risk of a multitude of anthropogenic threats, such as those previously described for cetaceans: incidental by-catch in fishing gear, exposure to pathogens and pollutants, collisions with shipping vessels, and underwater noise [12]. Recent studies off the southwest peninsula of the UK (including Cornwall) have afforded some insights into the distribution of short-beaked common dolphin (Delphinus delphis) [13] [14]. Others report on opportunistic or short-temporal studies of harbour porpoise (Phocoena phocoena) and bottlenose dolphin (Tursiops truncates) [15] [16] [17] [18]. However, no long-temporal datasets are available for marine megafauna within these waters. The basking shark (Cetorhinus maximus) is poorly studied and believed to seasonally aggregate within the region with the southwest of the UK identified as one of three hotspots in UK waters [10] [19] [20]. The ocean sunfish (Mola mola) is also relatively little known and is most commonly sighted during summer [3] [5] [21]. The widely dispersed leatherback turtle (Dermochelys coriacea) is believed to regularly occur in UK waters but in relatively small numbers [7] [8] [10] [22].

The protection of marine megafauna within Europe is rather fragmented. The EU Habitats Directive describes both habitats and species that are to be protected, based on which Special Areas of Conservation (SAC) can be designated. All cetacean species occurring in Europe are listed in Annex IV of the Directive, requiring strict protection, and the harbour porpoise and bottlenose dolphin are 
also listed in Annex II for which SACs can be designated. Basking sharks are classified as "Endangered" in the northeast Atlantic by the International Union for Conservation of Nature (IUCN) but they are not listed as Annex II or IV species, and its protection is limited to national legislation. Cetaceans and basking sharks are both listed as UK Biodiversity Action Plan target species and as Priority Marine Features. The Ocean Sunfish has not been evaluated by the IUCN, and is not covered by European protective or UK legislations. Leatherback turtles are listed on Appendix 1 of the Convention on the International Trade in Endangered Species of Flora and Fauna (CITES) 1975, Appendix II of the Bern Convention 1979, Appendix I and II of the Bonn Convention 1979 and Annex IV of the EC Habitats directive. Marine Conservation Zones (MCZs) are now being designated for nationally important habitats and species in territorial and UK offshore waters [23] and all these different protected sites are contributing towards an international ecologically coherent network of Marine Protected Areas (MPAs). In order to identify suitable protection areas for marine megafauna, up to date information is essential about their fine-scale distribution and their interactions with the physical and biological environment. However, well-designed systematic surveys are often restricted to short periods in time and are not designed to study the fine-scale distribution patterns in high density areas [24]. Recent studies have shown that such "knowledge gaps" can be filled in by so-called Platforms of Opportunity ( $\mathrm{PO}-$ for example a ferry or a cruise vessel; e.g. [25] which create low-cost approaches [26] [27]). However, the routes for these platforms are not determined by the research design and basic statistical design requirements are compromised [28]. Nevertheless, relating animal sightings to effort can often be used directly to infer relative distributions (e.g. [25] [26] [27]). A PO can also be that of a wildlife tour operator (WTO), which typically determines the track line in situ, often according to prevailing environmental conditions (e.g. [29]). These platforms are in the position to collect more accurate visual and behavioural data when approaching animals and confirm species, gender or group size [30]. For some time, recommendations have been made supporting the development of systematic data collection protocols to secure the collection of high quality data from WTOs (i.e. whale-watch; [31] [32] [33] [34] [35]). However, to date, the number of WTOs actively collecting data related to distribution and relative abundance of marine fauna such as cetaceans remain limited. Nowadays, most data collected from WTOs consist of opportunistic sightings only and when effort data is not collected, the type of data analysis is much reduced [25]. Survey effort provides the much needed information to identify high density areas and can even improve designing future dedicated research surveys [36] [37]. However, temporal and spatial effort information is often not adequately recorded by WTOs [34]. WTOs may typically visit locations where they believe they have a better chance of finding animals and as such the sighting rates of species will be relatively high. They may also change their course and speed to increase the time spent in the vicinity of the animals during each trip. Few studies have analysed effort-corrected data facilitated by 
WTOs by using the vessel's Global Positioning System (GPS) track as an indication of effort [38] [39]. In the Pacific, special software was recently produced to facilitate systematic data recording from large whale-watch vessels with an option to upload GPS tracks to determine the distance and area covered by the vessels [40].

In this study, we investigate whether regularly collected (effort-corrected) data on marine megafauna facilitated by a WTO afford robust long temporal data (2011-2015). This data, collected from a sailing catamaran in the wider Mount's Bay area off Penzance in Cornwall, allow for the fine-scale examination on the occurrence and distribution patterns of marine megafauna. As such, these new insights provide important baseline data on areas of high density beyond the resolution of most studies and management considerations.

\section{Materials and Methods}

\subsection{Study Area}

The study was undertaken between between $49^{\circ} 55^{\prime} \mathrm{N}-50^{\circ} 08^{\prime} \mathrm{N}$, and $5^{\circ} 22^{\prime} \mathrm{W}$ $5^{\circ} 45^{\prime} \mathrm{W}$ off southern Cornwall (Figure 1) between 2011 and 2015. The study area is wind exposed and tidally dominated precluding regular boat surveys at certain times of the year and as such creating a challenging environment for data collection. The area includes the Mount's Bay region, a coastal habitat following the southerly coastline and stretching out towards the Runnelstone Reef (off Land's

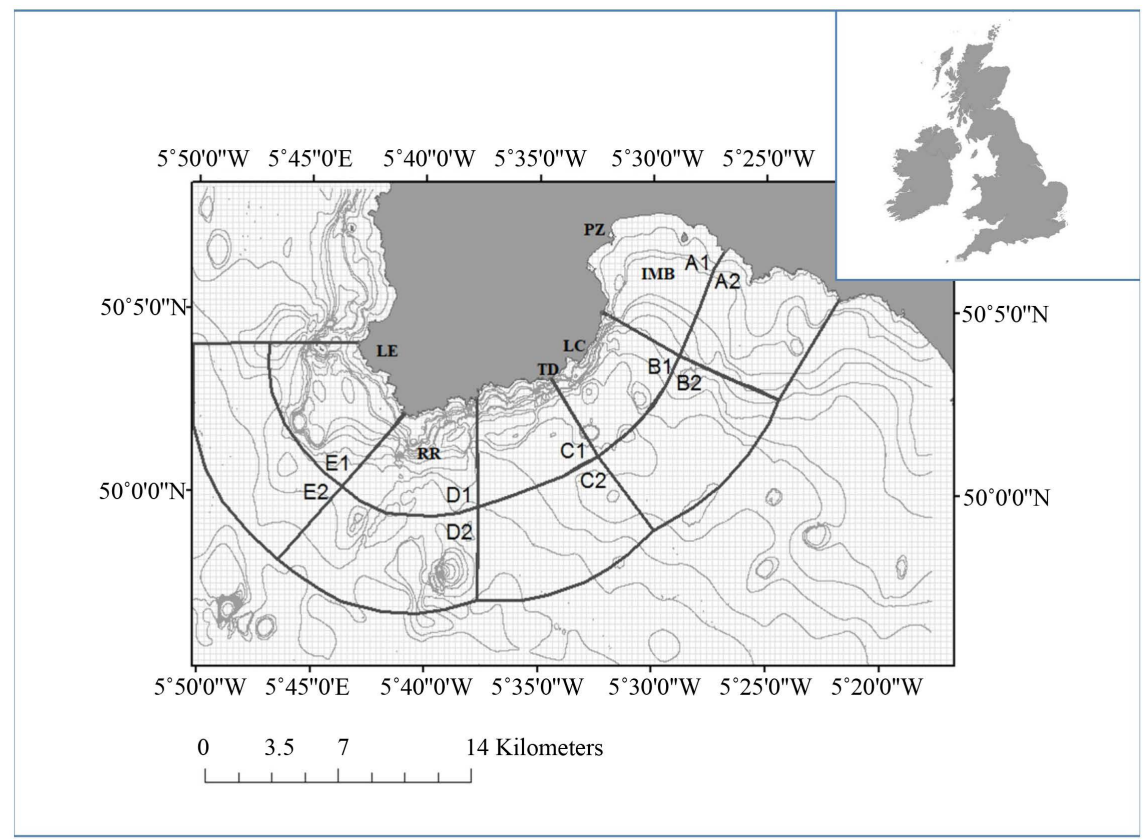

Figure 1. Map of the Wider Mount's Bay area in Cornwall, UK. The black lines show inshore sectors (A1-E1 \& A2) and offshore sectors (A2-E2). Grey lines show isobaths (10-60 $\mathrm{m}$ water depth). The survey area with $300 \times 300 \mathrm{~m}$ grid cells is shown in light grey. Inset: location of Mount's Bay relative to the UK. The positions of Penzance (PZ); Land's End (LE); Runnestone Reef (RR), Inner Mount's Bay (IMB), Tater Du (TD) and Lamorna Cove (LC) are also shown. 
End) beyond which the water depth drops sharply to $>60 \mathrm{~m}$ (Figure 1). Broadscale tidal data from Admiralty Charts show that water is driven around this headland reef by the tidal current as it enters and exits the western Channel during a semi-diurnal tidal regime [41]. Tidal range varies from between 1.5 (neap tide) - $5.5 \mathrm{~m}$ (spring tide).

\subsection{Data Collection}

Marine fauna data were collected during boat surveys (platform of opportunity) operated by Marine Discovery Penzance, a commercial tour operator offering marine wildlife watching tours within Mount's Bay (Cornwall). The data were collected from the $S V$ Shearwater II (SW II), a sailing catamaran which occasionally uses $2 \times 9.8 \mathrm{hp}$ four-stroke Tohatsu outboard engines (these were replaced in 2014 by $2 \times 20 \mathrm{hp}$ four-stroke Tohatsu outboard engines). Boat surveys took place every year between mid-March/early April to late October/ mid-November. During passenger trips, systematic surveys were conducted by two experienced observers (e.g. captain and one dedicated crew) following "random transects", where the boat would stay on a randomly chosen straight line until the end of the transect section. This was usually determined by a sighting of marine megafauna (whale, dolphin, basking shark, turtle, ocean sunfish, seal and seabird of interest). Whilst on this line ("on effort"), the following environmental data were collected: position, course, speed, swell height, visibility and Beaufort sea state (BSS). During 2011-2013 the environmental data were updated for each trip and with every sighting. From 2014 onwards, environmental data were updated when conditions changed. GPS positions were obtained every minute as well as at sighting positions (plotting approximate position where the animal was first seen) using a Garmin GPS (GPSMAP76CSx). When a sighting was made (marking the end of a random transect section) the vessel would subsequently leave the track (i.e. "off-effort") and commenced data collection, i.e. estimated sighting position, species ID (graded as definite, probable, possible, or "dolphin sp"/“whale sp”), heading of animal(s), behaviour and group composition. Effort would be resumed once the boat began travelling along the next randomly selected transect course to continue searching for independent groups or individuals (i.e. spatially and/or temporally separated to prevent the same individuals becoming resampled [42].

A minimum group size was assessed visually and recorded for each encounter. A group of dolphins was defined as any number of individuals observed moving in the same general direction, engaged in the same activity or in apparent close association [43]. It was not always possible to assess if the same individuals/ groups were recorded on a subsequent survey within the same day and as a consequence some animals/groups may have been re-sampled. Starting on 8 April 2011, research trips were carried out when weather and sea conditions permitted. On average 205 trips per year were achieved. The vast majority of trips carried out were of 3 hours duration, although in the peak season there were weekly 
4 hour trips and daily evening 2 hour trips. The geography of the Mount's Bay area favoured some areas to be sheltered from prevailing south westerly weather conditions whilst other areas were surveyed less often, particularly in early spring and autumn. Where feasible, routes were selected to at least achieve equal survey coverage of the inshore waters ( $5 \mathrm{~km}$ from the south coast). Those offshore waters (between $5-10 \mathrm{~km}$ from the coast) were covered less regularly.

\subsection{Data Analysis (Effort-Corrected)}

Marine fauna data collected in slight BSS 0 - 4, moderate and good visibility ( $\geq 1$ $\mathrm{km})$ and low swells $(\leq 2 \mathrm{~m})$ were used for data analysis. All effort data collected in visibility of $<1 \mathrm{~km}$, in swell heights exceeding $2 \mathrm{~m}$ or in BSS $\geq 5$ were removed and associated sightings downgraded to incidental status. GPS positions (sightings and effort) were imported into ArcGIS version 10.2.1 (with the following coordinate system: Transverse_Mercator, Central_Meridian: -5.0, Latitude of Origin: 49.833, Linear Unit: Meter, Geographic Coordinate System: GCS_WGS_ 1984). A grid with a resolution of $300 \times 300 \mathrm{~m}$ was created, and cells with a survey effort $<10 \mathrm{~km}$ were excluded. The latitude and longitude were assigned to the centre of each grid cell when determining the mean water depth. The index of abundance ("relative abundance") was measured and expressed as the number of individuals per $100 \mathrm{~km}$ survey effort (ind $100 \mathrm{~km}^{-1}$ ). In addition, a grid with a resolution of $1200 \times 1200 \mathrm{~m}$ was created to plot the species richness within the study area. Bathymetry data (average seabed depth) were sourced from the Channel Coast Observatory data [44] at one meter resolution and covered those depths up to $30 \mathrm{~m}$. This data was combined with General Bathymetric Chart of the Oceans data [45] at a resolution of 30 arc seconds $(1 \mathrm{~km})$ for the Celtic Shelf. In order to create a geotiff depth file a number of steps were followed. Initially the GIS contour extraction tool was used to extract contours from a $30 \mathrm{sec}$ GEBCO. These contours were used alongside data collected from a course depth survey conducted onboard the $M V$ Shearwater $I I$ and using a depth sounder to collect spot depths. The spot depths were corrected to chart datum and used to increase the accuracy of the GEBCO contours. Local knowledge of the depths of certain wrecks and topographic features was also used. The combination of these three elements allowed an accurate vector file to be created with contours at -1 , $-5,-10,-20,-30,-35,-40,-45,-50,-55,-60,-65$ and -70 . The vector file was then loaded in the program GRASS (version 6.4.3) in order to convert it to a geotiff. The vector to raster tool was used to create raster contours after which the interpolation tool r.surf.contour was used to create the Depth file. The Depth file was then checked for accuracy against an Admiralty Chart [46].

\subsection{Detectability, Sea State and Survey Speed}

The ability of an observer to sight the animal is negatively affected by increasing distance between the animal and the observer and similarly by the BSS. Using data collected in 2015 regarding two positions, (1) the initial boat position (plotted 
as soon as a sighting was made) and (2) the estimated sighting position, we computed the radial and perpendicular distances for those cetacean species with a high enough sample size. We next studied the effect of distance on the detectability of sightings by plotting an accumulation curve which shows the proportion of total number of sightings up to a given distance [24]. This allowed us to estimate the "inflection point", which is the point marking the distance at which there is a change from constant to declining detection rate with distance (the point where the increase changes from linear increase to a curvilinear increase). This point represents the distance beyond which sightings are likely to be missed by the observer. Since small cetaceans are notoriously difficult to observe with a high BSS, we determined which BSS followed a similar accumulation curve and could therefore be pooled for analysis (i.e. which of the higher BSS needed to be excluded to reduce bias in the ability of detection). Finally, the effect of survey speed on the detectability of sightings was also explored using accumulation curves.

\subsection{Temporal Patterns}

We employed statistical tests using the statistical package PASW for windows (SPSS, Inc., version 21). For data analyses, we used meteorological seasons as spring (March through May), summer (June through August) and autumn (September through November). For seasonal statistical analysis a Chi-squared test of independence was used to assess the relationship between species index of abundance and season. A post hoc Pearson residuals analysis was carried out for Chi-squared significant values to determine which season explained the lack of independence. When sample size was small, a p-value approximation procedure was computed from a Monte Carlo test with 10,000 replicates within the Chisquared protocol [47]. We adjusted the counts for all taxa and species by using the index of abundance per season. We then rounded the numbers to derive standardized counts and analyses were carried out in SPSS (Inc., version 21).

\subsection{Spatial Patterns}

Firstly, potential differences in data collected over the five survey years were studied by segregation of the relative abundance of marine megafauna per grid cell by survey year. To determine whether species were randomly distributed throughout the years, a one-sided Kolmogorov-Smirnov goodness-of-fit test was used to check if the relative abundance of a species differed from a uniform distribution (i.e. all years were expected to have the same relative abundance). Next, the study area was divided into ten geographically distinct sub-regions; (1) inshore sub-regions within approximately $5 \mathrm{~km}$ from the coast (A1-E1); and (2) offshore sub-regions between approximately 5 and $10 \mathrm{~km}$ from the coast (A2-E2; Figure 1). While these regions are connected to each other, they could be easily identified from the boat and furthermore presented distinctive areas of marine megafauna habitat that differ in terms of their seabed topography, their proximity 
to the coast and their connection with the deep waters of the Celtic Sea (to the West of the study area). To identify areas of high density of marine megafauna, kernel density estimation grids were produced in ArcGis 10.2.1 using the Spatial Analyst tool "Kernel Density" to examine the relative densities of different species across the study area. Cell size for the kernel density estimation was set at 50 $\mathrm{m}$ and the search radius was set to $1000 \mathrm{~m}$ (Euclidean distance) to limit searching to surrounding grid cells only. The smaller cell size selected for the kernel density estimation was found to best relate to the resolution of the habitat variables and our fine-scale analysis. The selected value of $50 \mathrm{~m}$ was appropriate considering the error on the majority of sighting position estimates. The relative size and form of the kernel density estimate is dependent on the total number of locations and their distribution. To compensate for the large differences in the amount of survey effort we therefore treated the inshore sectors separately from the offshore ones. By determining the smallest possible area containing user specified percentages of the locations, the kernel grid was divided into percentage volume contours for $95 \%, 75 \%, 60 \%$ and $50 \%$ intervals. This means that the area within the $50 \%$ contour represents areas with highest sightings ('core habitats') and the $95 \%$ contour almost the entire range. The kernel contours (especially the larger ones) will extend onto land areas and thereby mask the coastline making the distribution maps difficult to read. In order to avoid this, the kernel contours are placed underneath the land layer on all maps. The resulting kernel density maps were visually assessed in order to identify any high density regions [48].

\section{Results}

\subsection{Detectability, Sea State and Survey Speed}

We studied the effect of distance and BSS on the number of porpoises, common dolphins and Risso's dolphins (Grampus griseus) by plotting accumulation curves which showed the proportion of total number of sightings within a given distance. As expected, the inflection point based on perpendicular distance $\left(i_{\text {perp }}\right)$ and radial distance $\left(i_{\text {rad }}\right)$ differed between species (Figure $2(a)$ ). The smaller cetaceans had lower inflection points for both perpendicular and radial distances compared to the larger Risso's dolphin (Table 1). From Figure 2(c) it is evident that for porpoises, the BSS2-3 followed a similar accumulation curve but for BSS4 this differed (inflection point is $33 \mathrm{~m}$, much lower than BSS0-3; Table 1). For common dolphins, we found a similar curve for BSS 2-3, and this also differed for BSS4 with a corresponding lower inflection point (79 m; Figure 2(d); Table 1). For Risso's dolphin data, BSS0-4 all showed similar curves although the inflection point was difficult to define for BSS4 but this was comparable to the curve for BSS2 (Figure 2(b)). The sighting rate for cetaceans reduced especially with speeds of $>8$ knots and $<2.1$ knots (Figure $2(\mathrm{e})$ ). The maximum speed measured was 15 knots, although this speed was rarely reached and was generally up to eight knots (92.3\% of all effort). It was decided to not include survey speeds of $<2$ knots for cetaceans and to exclude those speeds $>12$ knots. 


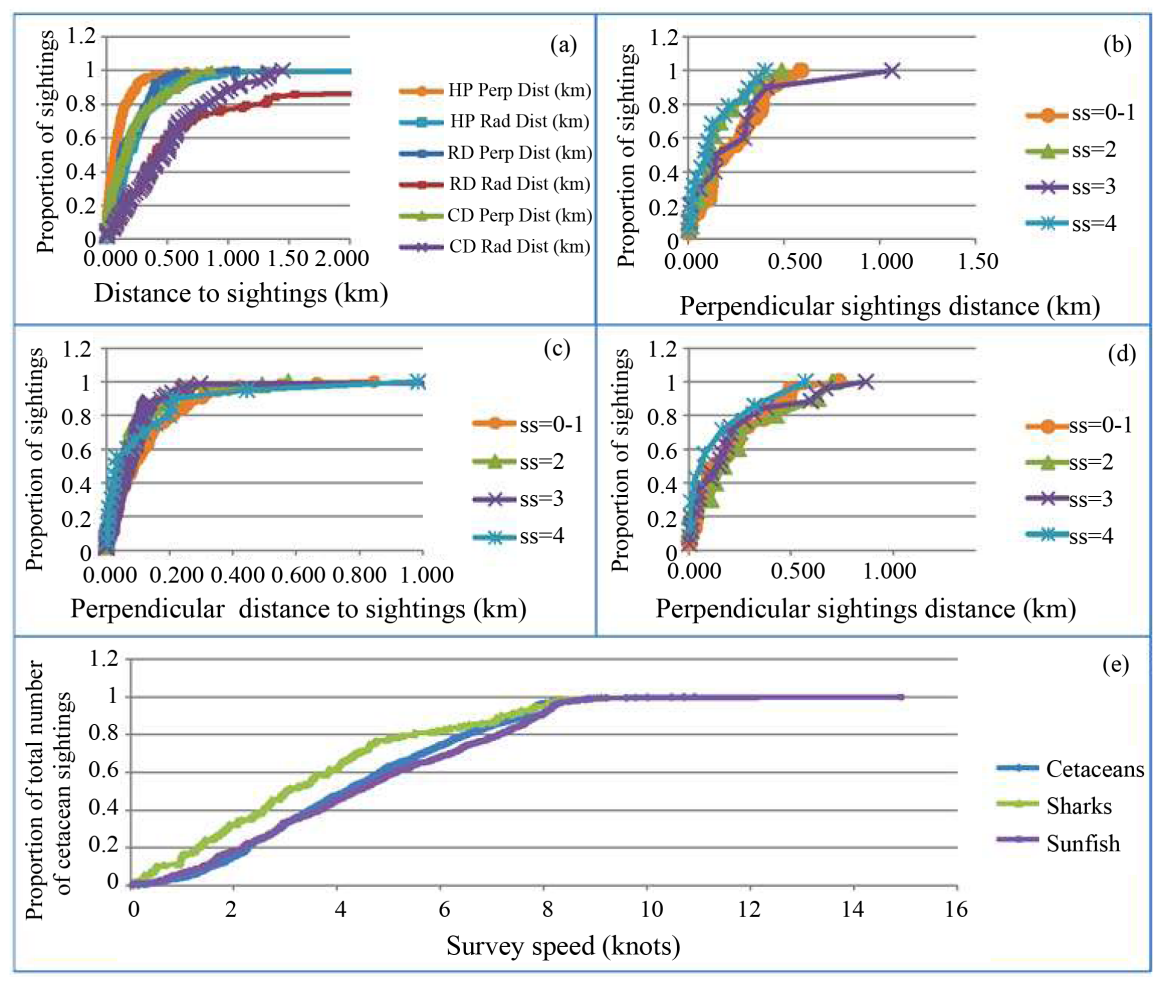

Figure 2. Accumulation curves plotted using different sightings data: (a) data based on both perpendicular and radial distances for harbour porpoise (HP), common dolphin (CD) and Risso's dolphin (RD); (b) perpendicular distance data collected during different sea states for Risso's dolphin; (c) harbour porpoise and (d) common dolphin; and (e) data in relation to survey speed (in knots) for cetaceans, basking sharks and sunfish.

Specifically slow speeds ( $<2$ knots) can best be regarded as those times when the operator was with marine fauna or passing slowly along coastal features. The accumulation curve for sharks in relation to survey speed showed a pronounced "kink" at 4.7 knots, however beyond this speed, sharks continued to be detected at a linear increase up to a speed of 8.1 knots. It was therefore decided to include slower survey speeds ( 1 knot) for sharks as (voluntary) speed restrictions apply when in vicinity of this species. On the basis of the outcome of these investigations, and in order to increase sample size, we decided to use data for porpoises and common dolphins collected at BSS0-3; $\geq 2$ knots survey speed; swell $\leq 2 \mathrm{~m}$; visibility $\geq 1 \mathrm{~km}$ (Filter 1). For Risso's and bottlenose dolphins we filtered for BSS0-4; $\geq 2$ knots; swell $\leq 2 \mathrm{~m}$; visibility $\geq 1 \mathrm{~km}$ (Filter 2) and for basking sharks for BSS0-4; $\geq 1$ knots; swell $\leq 2 \mathrm{~m}$; visibility $\geq 1 \mathrm{~km}$ (Filter 3; Table 2). No distance measures were taken for sunfish, but due to their small size we adopted filter 1 and data concerning other cetaceans were filtered using Filter 2 (Table 2). The sample size of turtle sightings was low and since these were recorded close inshore during times when the vessel was travelling with slower survey speeds we adopted filter 3 (Table 2). After filtering procedures, a total of 738 marine megafauna sightings were removed, the majority involving porpoises and sunfish. 
Table 1. Details on inflection points based on perpendicular sighting distances $(\mathrm{km})$ for different species during different sea state (ss) conditions.

\begin{tabular}{ccccc}
\hline \multirow{2}{*}{ Species } & \multicolumn{4}{c}{ Inflection point based on perpendicular distance $i_{\text {perp }}$} \\
\cline { 2 - 5 } & ss $=0-1$ & ss $=2$ & ss $=3$ & ss $=4$ \\
\hline Harbour porpoise & 141 & 90 & 117 & 33 \\
$\begin{array}{c}\text { Common dolphin } \\
\begin{array}{c}\text { Risso's } \\
\text { dolphin }\end{array}\end{array}$ & 239 & 243 & 202 & 79 \\
$\begin{array}{c}\text { Bottlenose } \\
\text { dolphin }\end{array}$ & 410 & 355 & 410 & 355 \\
\hline
\end{tabular}

a. Sample size not sufficient to compute detection curves, therefore assumed to be comparable to similarsized Risso's dolphin.

Table 2. Summary of the number of boat trips, survey effort and mean survey speeds between 2011-2015 from Shearwater II. Three different filtering settings are shown for different species groups: small species (harbour porpoise HP, common dolphin CD, sunfish SF), large species (bottlenose dolphin BND, Risso's dolphin RD, minke whale and baleen whales) and basking shark and turtle (sea state (SS); Good/Moderate visibility; survey speed in knots and swell in meters).

\begin{tabular}{|c|c|c|c|c|c|c|}
\hline \multirow[t]{2}{*}{ Survey period } & $\begin{array}{l}\text { Boat } \\
\text { trips }\end{array}$ & $\begin{array}{l}\text { Mean } \\
\text { survey } \\
\text { speed } \\
\text { (knots) }\end{array}$ & $\begin{array}{l}\text { All effort } \\
(\mathrm{km})\end{array}$ & $\begin{array}{c}\text { Effort }(\mathrm{km}) \\
\text { Filter } 1 \text { : SS } 0-3 \text {; } \\
\text { speed } \geq 2 ; \\
\text { swell } \leq 2\end{array}$ & $\begin{array}{c}\text { Effort }(\mathrm{km}) \\
\text { Filter 2: SS } 0-4 ; \\
\text { speed } \geq 2 ; \\
\text { swell } \leq 2\end{array}$ & $\begin{array}{c}\text { Effort }(\mathrm{km}) \text { Filter } \\
\text { 3: SS } 0-4 ; \\
\text { speed } \geq 1 \\
\text { swell } \leq 2\end{array}$ \\
\hline & & & & $\mathrm{HP}, \mathrm{CD}, \mathrm{SF}$ & $\begin{array}{c}\text { BND, RD, } \\
\text { Minke whale, } \\
\text { Baleen whale }\end{array}$ & Shark, Turtle \\
\hline $\begin{array}{c}08 \text { April-2 } \\
\text { October } 2011\end{array}$ & 203 & 5.73 & 6240.6 & 3834.9 & 4640.0 & 5056.4 \\
\hline $\begin{array}{c}18 \text { March-17 } \\
\text { November } 2012\end{array}$ & 208 & 6.13 & 6647.7 & 3766.5 & 5122.9 & 5470.2 \\
\hline $\begin{array}{c}17 \text { March-17 } \\
\text { November } 2013\end{array}$ & 208 & 5.67 & 6984.8 & 4507.9 & 5926.8 & 6018.5 \\
\hline $\begin{array}{c}8 \text { April-30 } \\
\text { October } 2014\end{array}$ & 205 & 6.21 & 7530.5 & 5050.9 & 6523.7 & 6617.9 \\
\hline $\begin{array}{c}2 \text { April-25 } \\
\text { October } 2015\end{array}$ & 203 & 6.06 & 7218.9 & 4879.1 & 6008.5 & 6110.7 \\
\hline 2011-2015 & 1027 & 5.96 & 34622.5 & 22039.3 & 28221.9 & 29273.7 \\
\hline
\end{tabular}

\subsection{Effort and Sightings}

A total of 1027 surveys (boat trips; Table 2) were carried out between 8 April 2011 and 25 October 2015 representing $34622.5 \mathrm{~km}$. A total of 2369 sightings of approximately 12,819 individuals were made of the following species, including harbour porpoise, short-beaked common dolphin, bottlenose dolphin, Risso's dolphin, common minke whale (Balaenoptera acutorostrata), humpback whales (Megaptera novaengliae), a probable sei whale (Balaenoptera borealis), a probable dwarf sperm whale (Kogia sima), basking shark, blue shark (Prionace glauca), oceanic sunfish and leatherback turtle. The Beaufort Sea State (BSS) during the observations ranged from 1 to 6 . The observation effort was split across BSS 0 (10.65\%), BSS 1 (11.97\%), BSS 2 (12.11\%), BSS 3 (32.71\%), BSS 4 (19.28\%), 
BSS $5(11.46 \%)$ and BSS $6(1.82 \%)$ with a total of $13.28 \%$ of effort occurring during BSS $\geq 5$. Most effort (in favourable conditions; Table 3) was conducted in $2014(21.79 \%)$, closely followed by 2015 (20.89\%), 2013 (20.21\%), 2012 (19.24\%), 2011 (17.88\%). The harbour porpoise was by far the most frequently observed species $(n=762$; filter 1$)$, followed by the sunfish $(n=380$; filter 1$)$,

Table 3. Summary of marine fauna sightings made between 2011 and 2015 from the Shearwater II during different effort-filters (effort-filters 1 - 3, Table 2). The abundance index for all marine megafauna is based on the maximum amount sightings made during favourable conditions (as per effort-filter 3, Table 2).

\begin{tabular}{|c|c|c|c|c|c|c|}
\hline \multirow{2}{*}{ Species } & \multicolumn{2}{|c|}{2011} & \multicolumn{2}{|c|}{2012} & \multicolumn{2}{|c|}{2013} \\
\hline & S & Ind $/ 100 \mathrm{~km}$ & $S$ & Ind $/ 100 \mathrm{~km}$ & S & Ind/100 km \\
\hline Harbour porpoise & $105(394)$ & 10.274 & $117(361)$ & 9.584 & $202(1051)$ & 23.315 \\
\hline $\begin{array}{c}\text { Bottlenose } \\
\text { dolphin }\end{array}$ & $9(108)$ & 2.328 & $3(14)$ & 0.273 & $3(31)$ & 0.523 \\
\hline Common dolphin & $39(526)$ & 13.716 & $27(796)$ & 21.134 & $37(1048)$ & 23.248 \\
\hline Risso's dolphin & $2(9)$ & 0.194 & $5(55)$ & 1.074 & $1(6)$ & 0.101 \\
\hline Minke whale & $2(2)$ & 0.043 & $0(0)$ & 0 & $2(2)$ & 0.034 \\
\hline $\begin{array}{l}\text { Large baleen } \\
\text { whale }\end{array}$ & $1(1)$ & 0.022 & 0 & 0 & 0 & 0 \\
\hline Kogia sp. & 0 & 0 & 0 & 0 & 0 & 0 \\
\hline Basking shark & $8(8)$ & 0.158 & $37(38)$ & 0.695 & $71(103)$ & 1.711 \\
\hline Blue shark & 0 & 0 & 0 & 0 & $1(1)$ & $\mathrm{n} / \mathrm{a}$ \\
\hline Ocean sunfish & $45(50)$ & 1.304 & $94(106)$ & 2.814 & $141164)$ & 3.638 \\
\hline Leatherback turtle & $1(1)$ & 0.026 & $7(7)$ & 0.186 & $2(2)$ & 0.044 \\
\hline All megafauna & $\begin{array}{c}260 \\
(1235)\end{array}$ & 24.424 & 416 (1907) & 34.862 & $559(2948)$ & 48.982 \\
\hline \multirow{2}{*}{ Species } & \multicolumn{2}{|c|}{2014} & \multicolumn{2}{|c|}{2015} & \multicolumn{2}{|c|}{ 2011-2015 } \\
\hline & $S$ & Ind $/ 100 \mathrm{~km}$ & $S$ & Ind $/ 100 \mathrm{~km}$ & $S$ & Ind $/ 100 \mathrm{~km}$ \\
\hline Harbour porpoise & $141(594)$ & 11.760 & $197(1045)$ & 21.418 & $762(3,445)$ & 15.631 \\
\hline $\begin{array}{c}\text { Bottlenose } \\
\text { dolphin }\end{array}$ & 15 (177) & 2.713 & $2(20)$ & 0.333 & $32(350)$ & 1.240 \\
\hline Common dolphin & $39(632)$ & 12.513 & $57(1594)$ & 32.670 & $199(4596)$ & 20.854 \\
\hline Risso's dolphin & $6(30)$ & 0.460 & $56(475)$ & 7.905 & $70(575)$ & 2.037 \\
\hline Minke whale & $7(10)$ & 0.153 & $6(7)$ & 0.117 & $17(21)$ & 0.074 \\
\hline $\begin{array}{l}\text { Large baleen } \\
\text { whale }\end{array}$ & $1(1)$ & 0.015 & $2(2)$ & 0.033 & $4(4)$ & 0.014 \\
\hline Kogia sp. & $1(1)$ & 0.015 & 0 & 0 & $1(1)$ & 0.003 \\
\hline Basking shark & $10(12)$ & 0.181 & $9(9)$ & 0.147 & $134(169)$ & 0.577 \\
\hline Blue shark & 0 & 0 & 0 & 0 & $1(1)$ & 0.003 \\
\hline Ocean sunfish & $28(32)$ & 0.634 & $72(76)$ & 1.558 & $380(428)$ & 1.942 \\
\hline Leatherback turtle & $1(1)$ & 0.020 & 0 & 0 & $11(11)$ & 0.050 \\
\hline All megafauna & $\begin{array}{c}337 \\
(1860)\end{array}$ & 28.106 & $514(3788)$ & 61.990 & $2086(11,738)$ & 40.097 \\
\hline
\end{tabular}


common dolphin ( $n=199$; filter 1$)$ and basking shark $(n=134$; filter 3$)$, however the common dolphin was the most abundant species owing to the large size of the groups observed (Table 3 ). The inshore sectors (A1-D1) received the majority of effort (94.2\%; effort-filter 3) compared to the remaining sectors (A2 and E1) and those sectors located further offshore (B2-E2). The inshore sectors A1-B1 had 8,500 km effort coverage (filter 3), C1 had $6550 \mathrm{~km}$ and the coverage of D1 was lower $(4165 \mathrm{~km})$. The effort within E1 \& A2-D2 covered only between $200-400 \mathrm{~km}$ and the overall coverage within E2 was the lowest $(<10 \mathrm{~km})$. Similar findings were made when comparing the effort coverage using the other filters (filters 1-2).

\subsection{Species Diversity}

A total of 12 species of marine megafauna were recorded including cetaceans (8 species, $n=8)$, sharks $(n=2)$, turtle $(n=1)$, and large pelagic fish $(n=1)$. The megafauna community consisted mainly of odontocetes $(66.0 \%$ of all megafauna sightings) which in turn were dominated by porpoises $(71.7 \%$ of all odontocete sightings), small delphinids (18.7\%) and large delphinids (9.6\%). However, in terms of individuals, small delphinids dominated the odontocete community (representing $51.2 \%$ of the individuals). Sunfish formed $23.6 \%$ of the megafauna community, closely followed by sharks (8.3\%). Mysticetes and turtles were in the minority presenting only $1.3 \%$ and $0.7 \%$ of the community. The diversity was at its highest in 2014 and during the month of August $(n=10$; Figure 3). Species richness exceeded six species within sectors A1, B1 and D1 (Figure 4).

\subsection{Spatial and Temporal Patterns}

Most survey effort was carried out in summer, particularly in July (24.95\% of all effort) and August (25.94\%). Using the indices of abundance calculated for all marine megafauna (filter 3 ) it was evident that these varied significantly over the survey years $\left(\chi^{2}=29.130, \mathrm{p}<0.001\right)$. Their abundance peaked in 2015 (61.99 ind $100 \mathrm{~km}^{-1}$ ) and was significantly lower in 2011 (24.42; Figure 3). Seasonally, the pattern of marine megafauna distribution was significantly different $\left(\chi^{2}=\right.$ 44.547, $\mathrm{p}<0.001)$ with numbers peaking in autumn $\left(69.86\right.$ animals $\left.100 \mathrm{~km}^{-1}\right)$.

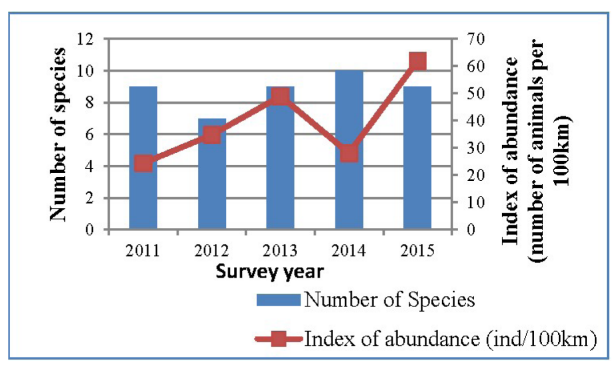

(a)

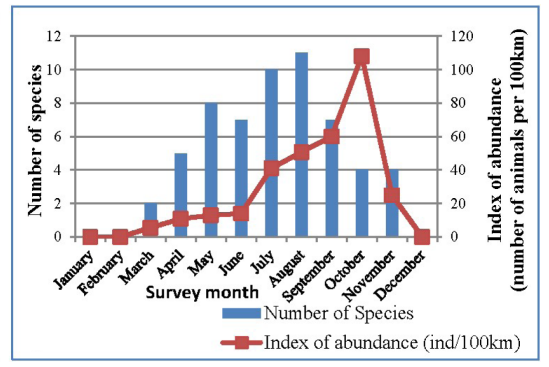

(b)

Figure 3. Species Diversity The number of species observed together with the yearly (a) and monthly (b) indices of abundance for all marine megafauna measured as the number of animals $100 \mathrm{~km}^{-1}$ during favourable survey conditions. 


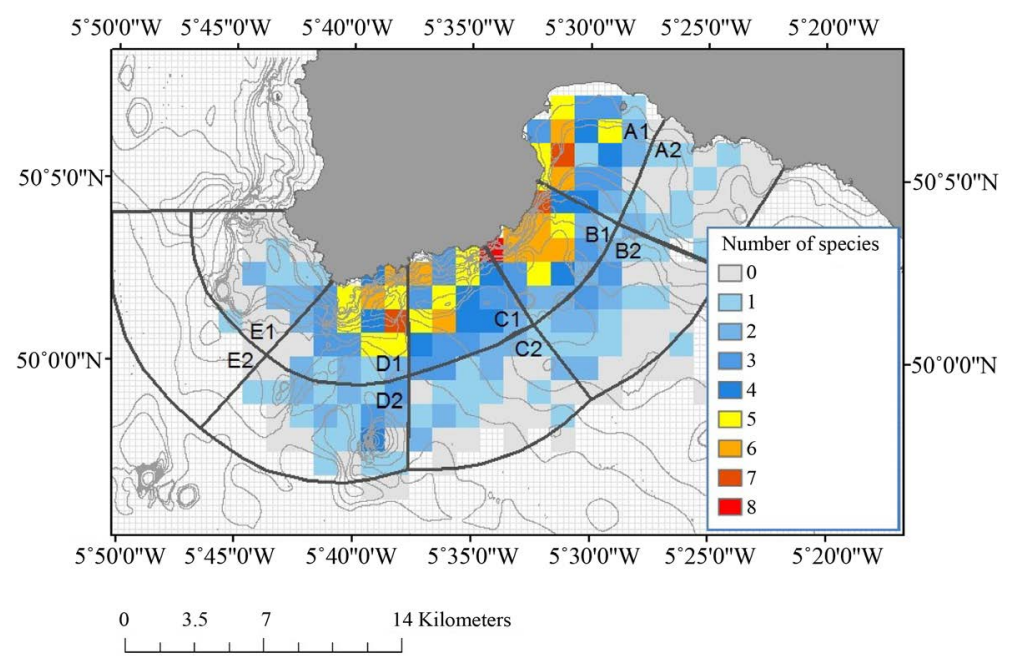

Figure 4. Species Richness-The number of species counted within each $1200 \times 1200$ m grid cell.

Cetaceans were mostly recorded during autumn and less frequently during spring $\left(\chi^{2}=39.537, \mathrm{p}<0.001\right)$, and similar findings were made for odontocetes $\left(\chi^{2}=39.735, \mathrm{p}<0.001\right)$ and mysticetes $\left(\chi^{2}=9.834, \mathrm{p}=0.007\right)$. Sharks however were more abundant during summer and to a lesser degree in spring $\left(\chi^{2}=8.950\right.$, $\mathrm{p}=0.011)$. Sunfish were more abundant during summer and least abundant during spring $\left(\chi^{2}=39.901, \mathrm{p}<0.001\right)$. The spatial pattern of all marine megafauna was distributed significantly different $\left(\chi^{2}=44.547, \mathrm{p}<0.001\right)$ with the relative abundance peaking in sector B1 (104 ind $\left.100 \mathrm{~km}^{-1}\right)$. Kernel methods were used to analyse spatial clustering in the sightings data within the inshore sectors (A1-D1). From the kernel density percent volume contours it is evident that marine megafauna showed two high density areas with one area spanning both D1 and $\mathrm{C} 1$ and the other spanning A1-C1 (Figure 5). The 50\% kernel volume contour for all marine megafauna within the inshore waters involved a total core area of $21.2 \mathrm{~km}^{2}$.

\section{Finding per Species}

\subsection{Harbour Porpoise (Phocoena phocoena)}

The harbour porpoise was observed in all months (March-November; Figure 6(a)) and was the most frequently recorded species with 762 sightings (3445 individuals) including 970 calves (defined as an animal less than one metre in length; [49]. The abundance of porpoises peaked in 2013 (23.3 animals 100 $\left.\mathrm{km}^{-1}\right)$ but in 2012 this was significantly lower $\left(9.6 ; \chi^{2}=10.828, \mathrm{p}=0.029\right.$; Figure $6(c)$ ). Porpoises were observed predominantly within the inshore regions (Figure 7) with the majority occurring in sector B1 (28 porpoises $100 \mathrm{~km}^{-1}$ ). One large area within 2 - $3 \mathrm{~km}$ from the coast, spanning sectors A1-B1 and another spanning C1-D1 can be regarded as high density core areas where porpoises regularly occur (50\% of all observations; Figure $7(\mathrm{~b})$ ). The $50 \%$ kernel volume 


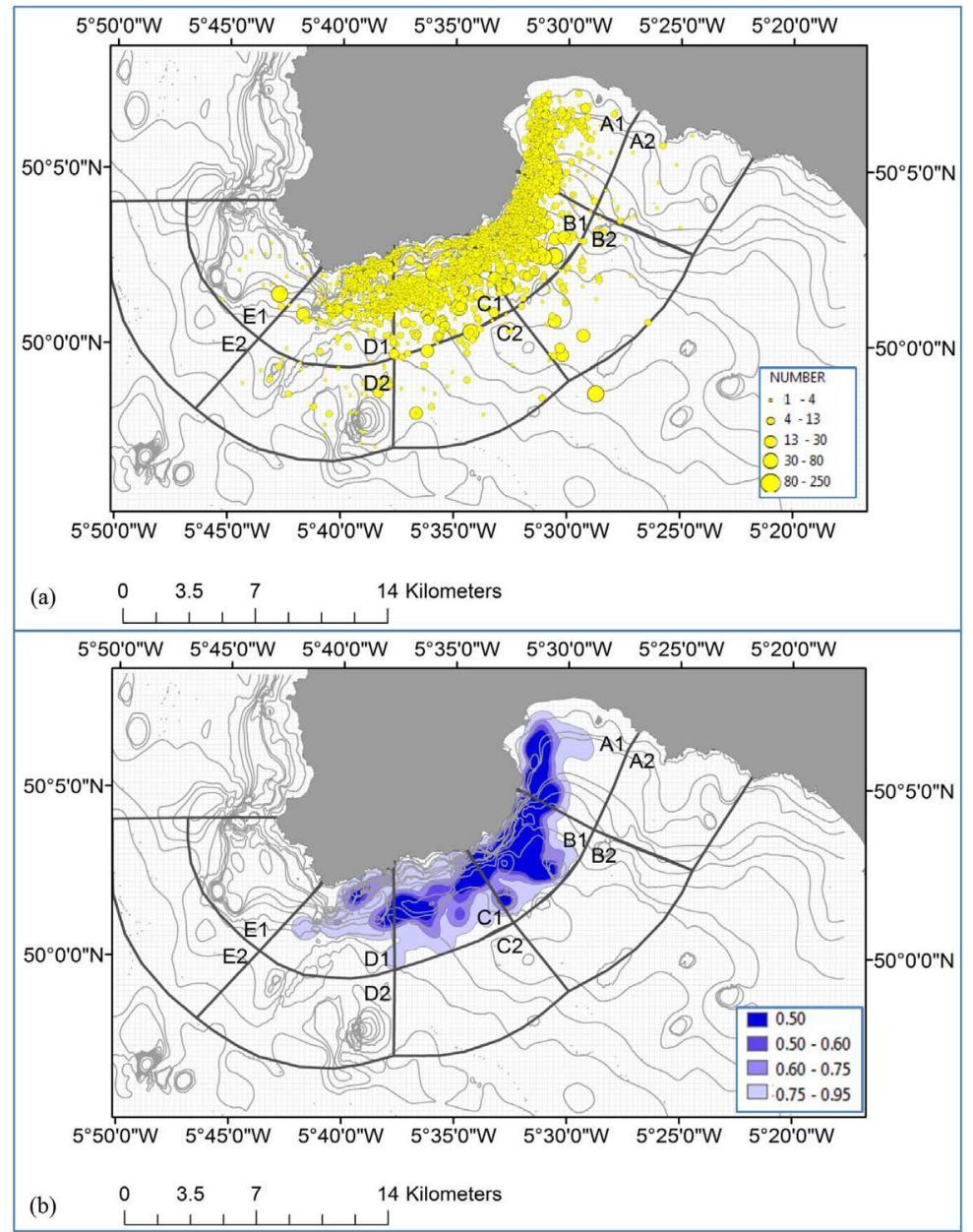

Figure 5. Sightings of marine megafauna (a) and kernel density utilisation grids plotted for inshore sectors (b). Densities are presented in percentiles (50\%; 60\%; 75\%; 95\%). Sighting locations are indicated by small circles relative to group-size.

contour for porpoises within these inshore waters involved a total area of 17.7 $\mathrm{km}^{2}$. Porpoises were mostly seen solitarily but also in small groups (mean $=4.52$; SD 4.38; range 1 - 40).

Most sightings were made in summer but in autumn they were frequently encountered in larger groups (autumn: $36.8 \%$ of all sightings involved groups $>5$ individuals; summer: 27.7\%; spring: 3.5\%). In summer, large groups of up to 20 individuals were observed in feeding areas. In autumn the groups in feeding areas occasionally reached up to 30 - 40 animals. This is reflected in the abundance index of porpoises which was significantly higher in autumn (29.44 ind $100 \mathrm{~km}^{-1}$ ) compared to summer (13.54 ind $100 \mathrm{~km}^{-1}$ ) and spring (2.44 ind 100 $\left.\mathrm{km}^{-1} ; \chi^{2}=47.689, \mathrm{p}<0.001\right)$.

Porpoises were either observed travelling (51.8\% of all records) or foraging (46.7\%). Other behaviours observed included resting/logging $(1.1 \%$ of all records), socialising $(2.6 \%)$, breaching $(\mathrm{n}=1)$ and courtship $(\mathrm{n}=1)$. During 


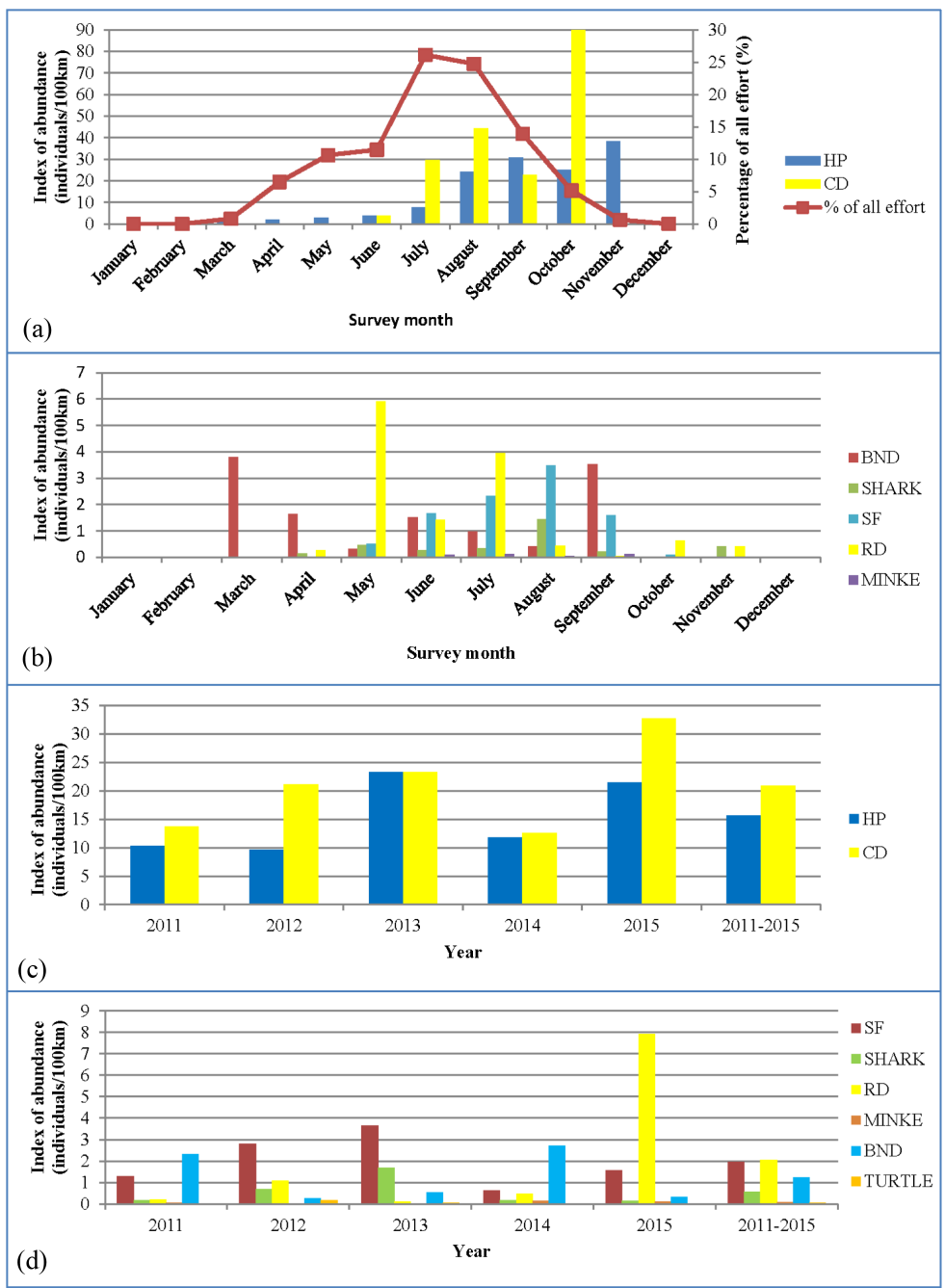

Figure 6. The indices of abundance as the number of individuals per $100 \mathrm{~km}$ effort calculated for different species per survey month (a) (b) and per survey year (c) (d); Harbour porpoise (HP), Common dolphin (CD); Bottlenose dolphin (BND), Basking shark (SHARK), Sunfish (SF), Risso's dolphin (RD), minke whale (MINKE) and leatherback turtle (TURTLE). Information on survey effort is depicted as percentage of survey effort for each survey month (a).

foraging the porpoises were often associating with diving gannets (Morus bassanus, $37.9 \%$ of all foraging records).

On 9 May 2015 an adult porpoise was encountered with what appeared to be a new born calf. The calf was swimming erratically making regular directional changes. The calf propelled half its body length vertically out of the water showing clear foetal folds. The mother was close by at all times, whilst slowly surfacing at regular intervals during which the calf moved erratically around her. This was the first time a calf had been recorded this soon after birth.

\subsection{Short-Beaked Common Dolphin (Delphinus delphis)}

Common dolphins were seen from April to November (Figure 6(a)) and they 


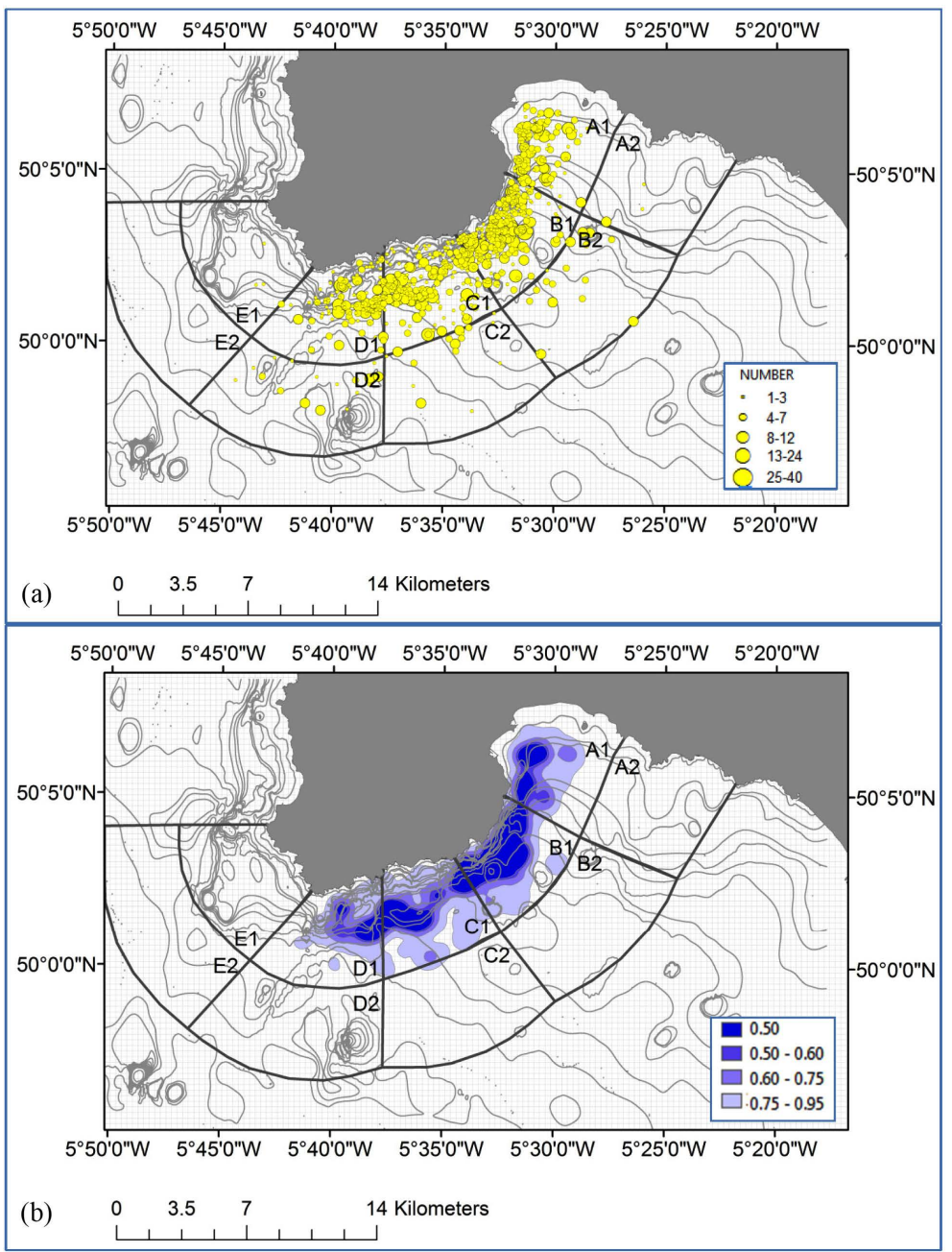

Figure 7. Sightings of harbour porpoise (a) and kernel density utilisation grids plotted for inshore sectors (b). Densities are presented in percentiles (50\%; 60\%; 75\%; 95\%). Sighting locations are indicated by small circles relative to group-size.

were the third most frequently sighted with a total of 199 sightings (4596 individuals). At least 1113 young (juveniles and calves) were recorded accounting for $24.2 \%$ of all dolphins. The species was most abundant within the inshore sectors and specifically in sector B1 (0.82 ind $\mathrm{km}^{-1}$ ) but significantly less abundant in A1 (19 dolphins $100 \mathrm{~km}^{-1}$ ). Common dolphins were occasionally observed in large groups offshore (B2-C2, Figure 8(a)). The dolphins used several core areas, the largest of which were situated within B1-C1 (Figure 8(b)). The $50 \%$ kernel volume contour for common dolphins within these inshore waters involved an area of $16.1 \mathrm{~km}^{2}$. Common dolphins showed no yearly variations with similar sighting distributions between 2011 and 2014 however their abundance significantly peaked in 2015 (32.67 dolphins $\left.100 \mathrm{~km}^{-1} ; \chi^{2}=15.658, \mathrm{p}=0.004\right)$. Common dolphins were usually recorded in large active groups (mean 23.21; SD 29.47; range 1 - 250). For the majority these dolphins were recorded in active foraging groups (59.8\% of all sightings) and were often accompanied by 


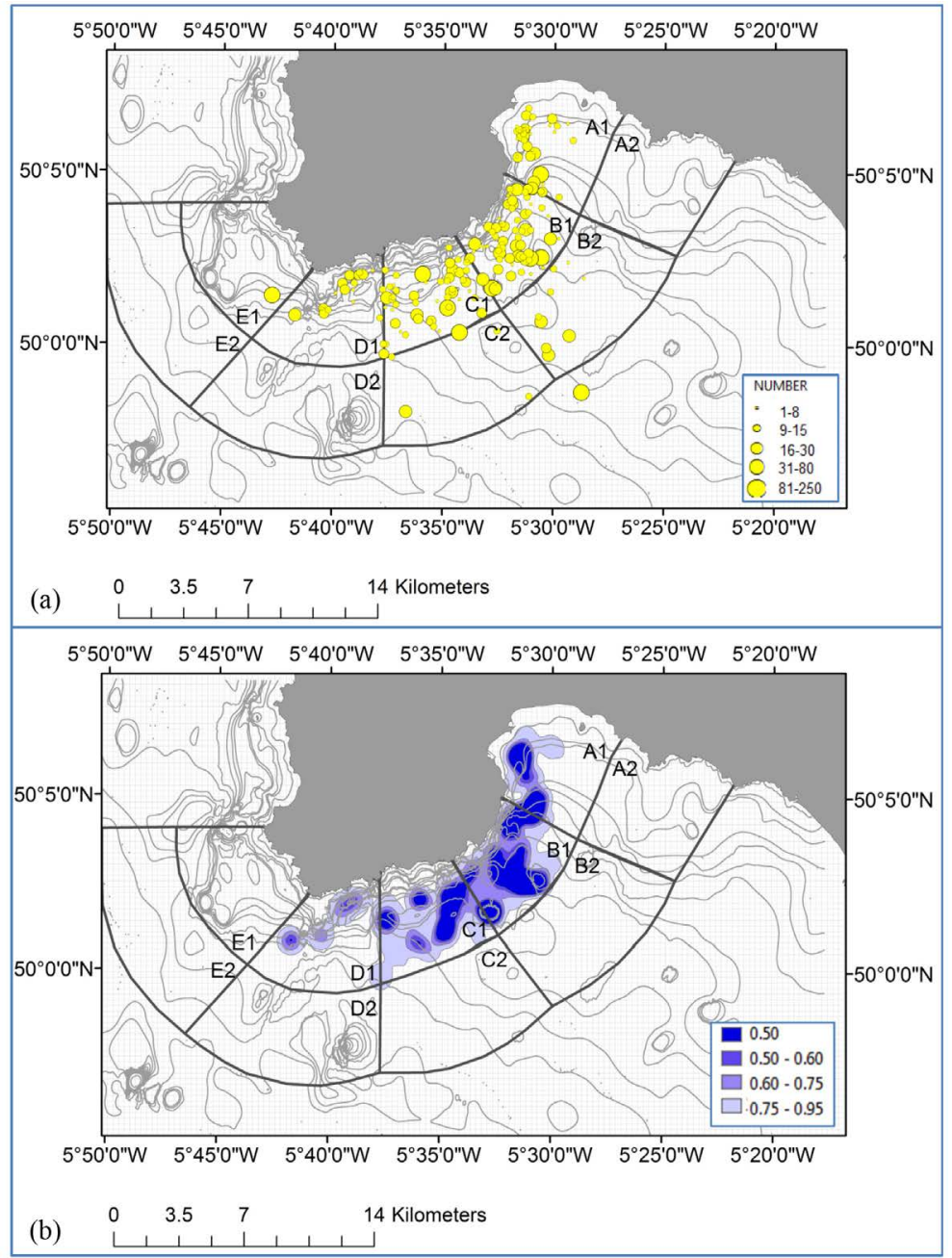

Figure 8. Sightings of common dolphin (a) and kernel density utilisation grids plotted for inshore sectors (b). Densities are presented in percentiles (50\%; 60\%; 75\%; 95\%). Sighting locations are indicated by small circles relative to group-size.

feeding (diving) gannets (29.2\%), particularly from 2012 onwards. Other cetacean species that associated with common dolphins during feeding frenzies included harbour porpoise $(\mathrm{n}=3)$, Risso's dolphins $(\mathrm{n}=2)$ and minke whale $(\mathrm{n}=$ 1). The mean group-size of dolphins was the highest in autumn (25.02) compared to summer (22.88) and spring (10.8). The seasonal distribution of common dolphins showed a significant pattern $\left(\chi^{2}=138.144, \mathrm{p}<0.001\right)$, with the highest numbers recorded in autumn (34.26 animals $\left.100 \mathrm{~km}^{-1}\right)$.

\subsection{Risso's Dolphin (Grampus griseus)}

The Risso's dolphins were seen from April-November (Figure 6(b)) on 70 occasions (575 individuals) involving 160 young. The Risso's dolphins used one larger core area overlapping sectors A1-B1 and a smaller (low density) area in sectors $\mathrm{C} 1$ (Figure 9) and were most abundant in $\mathrm{A} 1$ (3.81 ind $100 \mathrm{~km}^{-1}$; Figure 9). 


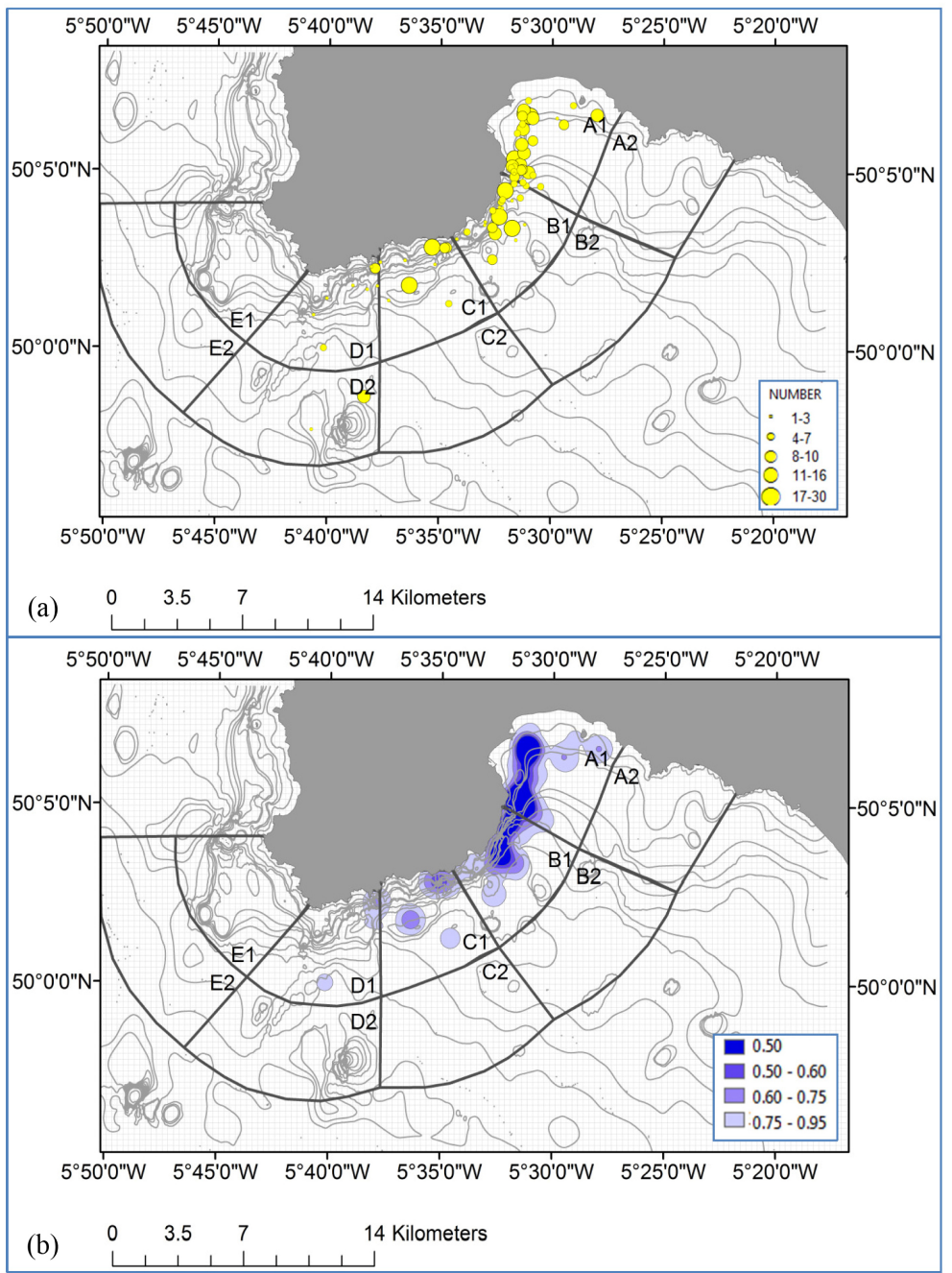

Figure 9. Sightings of Risso's dolphin (a) and kernel density utilisation grids plotted for inshore sectors (b). Densities are presented in percentiles $(50 \%$; $60 \%$; $75 \%$; $95 \%)$. Sighting locations are indicated by small circles relative to group-size.

Further offshore the species was recorded on two occasions. The $50 \%$ kernel volume contour for Risso's dolphins within sectors A1-B1 involved a total area of $6.8 \mathrm{~km}^{2}$. Whereas their numbers were low during the first four years they significantly increased in numbers in 2015 (Figure 6(d); 7.9 animals $100 \mathrm{~km}^{-1} ; \chi^{2}=$ 523.080, $\mathrm{p}<0.000$ ). Risso's dolphins showed no seasonal pattern between 2011 and 2014, however their numbers peaked in spring (3.56 ind $\left.100 \mathrm{~km}^{-1}\right)$ but less so in autumn $\left(0.21 ; \chi^{2}=15.529, \mathrm{p}<0.001\right)$. Risso's dolphins were seen in groups ranging between 1 and 30 dolphins (mean 8.11; SD 8.73) with larger groups in spring (mean 9.24) and summer (mean 7.89). They were associating with common dolphins in July $(\mathrm{n}=2)$. The dolphins were mainly travelling $(57.1 \%$ of records), feeding (32.5\%) or socializing (10.4\%). One severely malnourished and wounded Risso's dolphin was observed over several days in August 2015.

Risso's dolphins that showed recognizable marks (nicks and/or scars on body 
and dorsal fin) were included to the photo-identification database. By the end of the survey period, the catalogue held 110 recognisable ('marked') individuals. Of these, 10 were photographed on both sides, 60 on left and 40 on right sides only. This means that an estimated minimum of 70 (assuming all 40 right sides correspond to the 60 left sides) and a maximum of 110 (supposing that all left and right sides are from different animals) dolphins occurred in Mount's Bay during the survey period. During 2015 alone, a total of 66 photo-matches were made involving 21 individuals over 85 days (26 May 2015-18 August 2015). In 2015, a total of 16 recognisable adults were accompanied by young. Of these, three were very young calves which were re-sighted fairly regularly. One adult was observed within Mount's Bay in 2012 and subsequently re-sighted in 2015 (1125 days later) with a new calf.

\subsection{Common Bottlenose Dolphin (Tursiops truncatus)}

A total of 32 sightings were made of bottlenose dolphins involving 350 animals including 83 young. The dolphins were mainly encountered $<1.5 \mathrm{~km}$ from the coast. They were mostly abundant in A1 (5.51 ind $100 \mathrm{~km}^{-1}$; Figure 10). The species also occurred in sector B2 which involved a large offshore group of at least 60 dolphins observed on 20 September 2014 at $5.5 \mathrm{~km}$ from the coast. The core areas for bottlenose dolphins overlapped with those for Risso's dolphins (Figure 10) but the 50\% kernel volume contour for bottlenose dolphins was slightly smaller $\left(5.5 \mathrm{~km}^{2}\right)$.

The index of abundance for the dolphins peaked in 2014 (2.71 animals 100 $\left.\mathrm{km}^{-1}\right)$ but was much lower in $2012\left(0.273 ; \chi^{2}=76.295, \mathrm{p}<0.001\right)$. Bottlenose dolphins were mostly seen in small groups of 4 (mode) but groups of up to 11 dolphins were recorded inshore (median 10.5; SD 10.15; range 1 - 60). The dolphins were mainly observed travelling $(59 \%)$ or socializing (40\%), especially when in larger groups (mean 12.5). The mean group-size was the highest in autumn (16.6) compared to summer (9.65) and spring (7.6). Bottlenose dolphins were significantly more abundant in autumn $\left(2.53\right.$ ind $100 \mathrm{~km}^{-1} ; \chi^{2}=9.955, \mathrm{p}=$ 0.007).

\subsection{Ocean Sunfish (Mola mola)}

The ocean sunfish was present from May-October (Figure 6(b)) and was the second most frequently recorded species with 380 sightings (428 individuals). They were mainly encountered solitary but small groups $(2-4)$ were occasionally recorded. The size of the disc was estimated to be $\leq 60 \mathrm{~cm}(83.7 \%$ of all records) but sizes up of $80-90 \mathrm{~cm}$ were recorded $(\mathrm{n}=20)$. Sunfish mainly occurred within the inshore regions and most specifically within D1 (2.52 ind 100 $\mathrm{km}^{-1}$ ) with a lowest abundance index measured for sector A1 $\left(1.0\right.$ ind $\left.100 \mathrm{~km}^{-1}\right)$. They were occasionally encountered further offshore (B2-D2) or within sector E1 (Figure 11). Two core areas within $2.5 \mathrm{~km}$ from the coast were identified from the kernel density plot: one spanning sectors A1-C1 and one closer inshore 


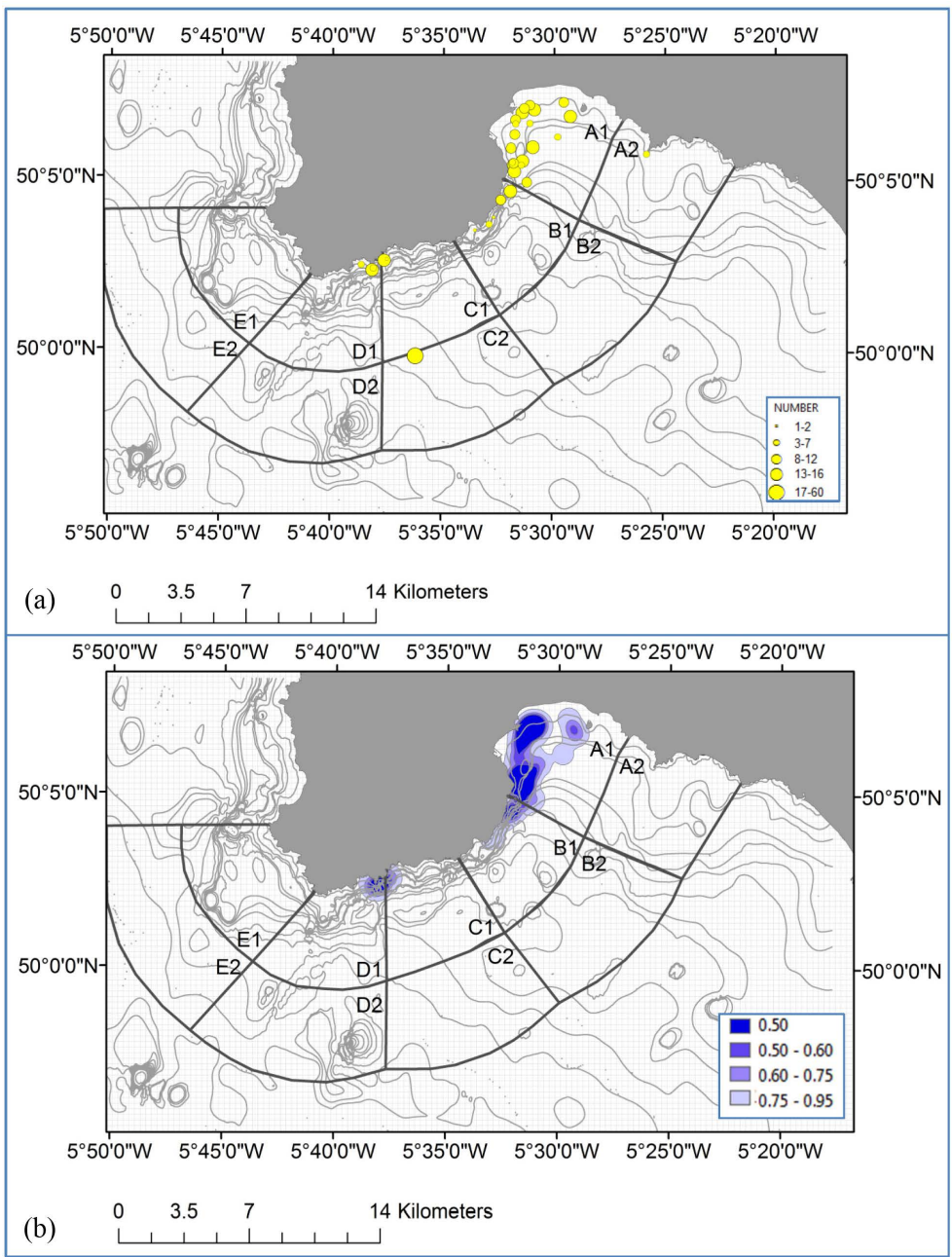

Figure 10. Sightings of common bottlenose dolphin (a) and kernel density utilisation grids plotted for inshore sectors (b). Densities are presented in percentiles $(50 \% ; 60 \% ; 75 \%$; 95\%). Sighting locations are indicated by small circles relative to group-size.

occurring in D1 (Figure 11). The 50\% kernel volume contour for sunfish involved a total area of $13.1 \mathrm{~km}^{2}$. The sunfish were usually observed basking at the surface (52\% of all records) or were actively travelling (35.0\%). The numbers of sunfish peaked in 2013 (3.64 animals $\left.100 \mathrm{~km}^{-1} ; \chi^{2}=35.594, \mathrm{p}<0.000\right)$ and during summer (June, August and September) but they were the least abundant during spring $\left(\chi^{2}=39.901, \mathrm{p}<0.001\right)$.

\subsection{Basking Shark (Cetorhinus maximus)}

Basking sharks were recorded in April-September and November (Figure 6(b)). Basking sharks mostly occurred within sectors A1-D1 but also further offshore (in A2, B2 and D2) with the highest counts made in B2 (Figure 12). The core area for basking sharks was mainly located close inshore, spanning sectors A1-D1 (Figure 12) with the 50\% volume contour involving an area of $12.6 \mathrm{~km}^{2}$. Some aggregations of feeding sharks ( 3 - 7 animals) were observed up to $5 \mathrm{~km}$ 


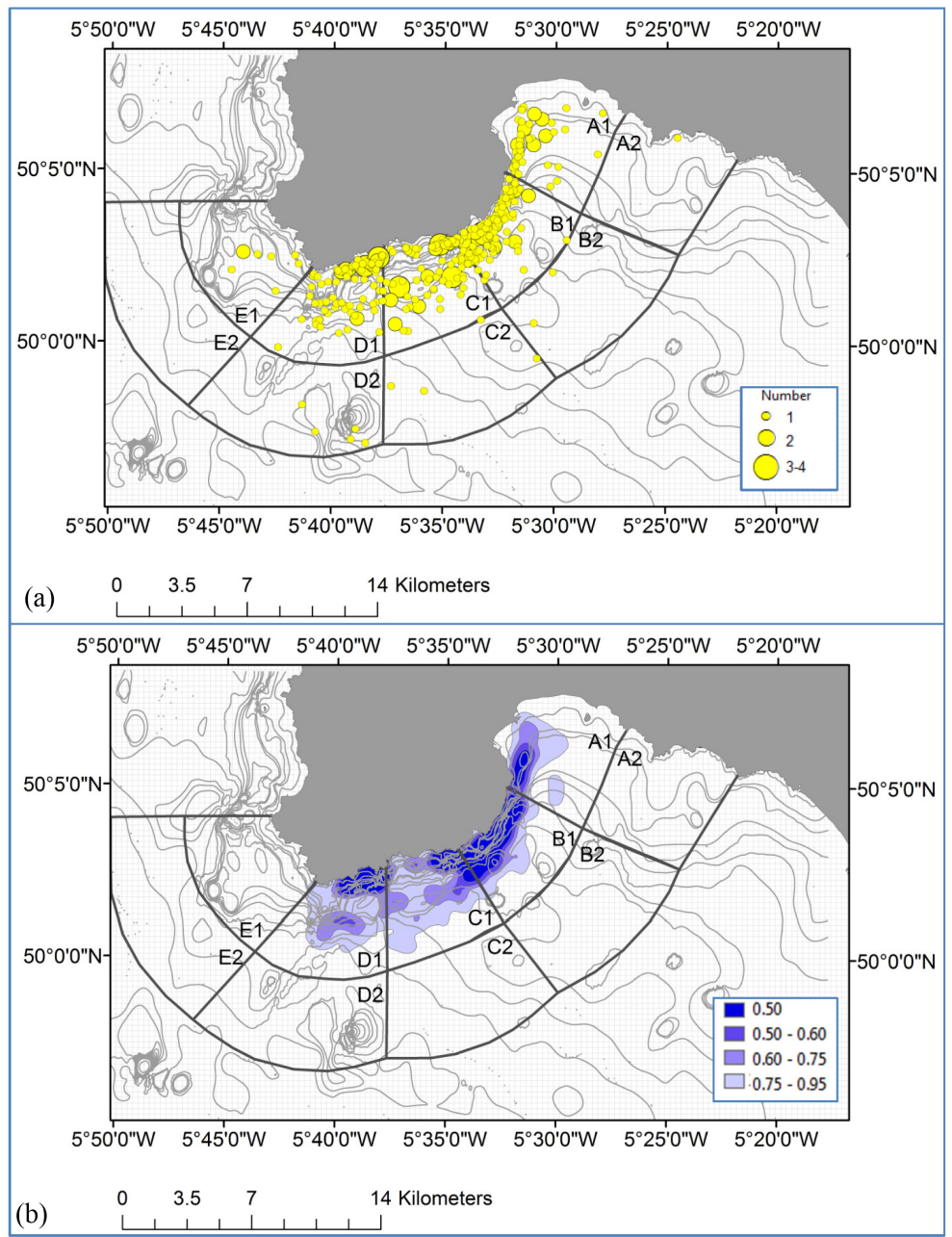

Figure 11. Sightings of sunfish (a) and kernel density utilisation grids plotted for inshore sectors (b). Densities are presented in percentiles $(50 ; 60 ; 75$; 95\%). Sighting locations are indicated by small circles relative to group-size.

offshore. Basking sharks were recorded on 134 occasions (169 individuals) with their numbers peaking in 2013 (1.70 animals $\left.100 \mathrm{~km}^{-1} ; \chi^{2}=136.030, \mathrm{p}<0.000\right)$. Basking sharks were usually encountered as solitary animals (mean 1.26; SD 0.84; range 1 - 7) but in August sharks occasionally aggregated in groups (3 - 7 sharks).

Sharks were mainly feeding just below the surface $(87.4 \%$ of all records) or were travelling $(8.9 \%)$ or breaching (3.7\%). In early august 2013, courtship-like behaviour was observed involving two sharks (estimated to be 5 and $8 \mathrm{~m}$ in length). The sharks were swimming nose to tail and circling each other (behaviour indicative of courtship [50]. Sharks were for the majority estimated to be between $4-6 \mathrm{~m}$ in length ( $68 \%$ of all records) but larger animals ( $7-8 \mathrm{~m}$ length) were also relatively frequent (15.3\%) and equally also smaller sharks $<4 \mathrm{~m}$ (16.7\%). Associations with other species were rarely observed but occasionally involved resting seabirds (Larus sp.) on the water. Sharks were most abundant during summer $\left(0.77\right.$ ind $\left.100 \mathrm{~km}^{-1}\right)$ and less so in autumn (0.17) and $\operatorname{spring}\left(0.33 ; \chi^{2}=8.950, \mathrm{p}=0.011\right)$. 


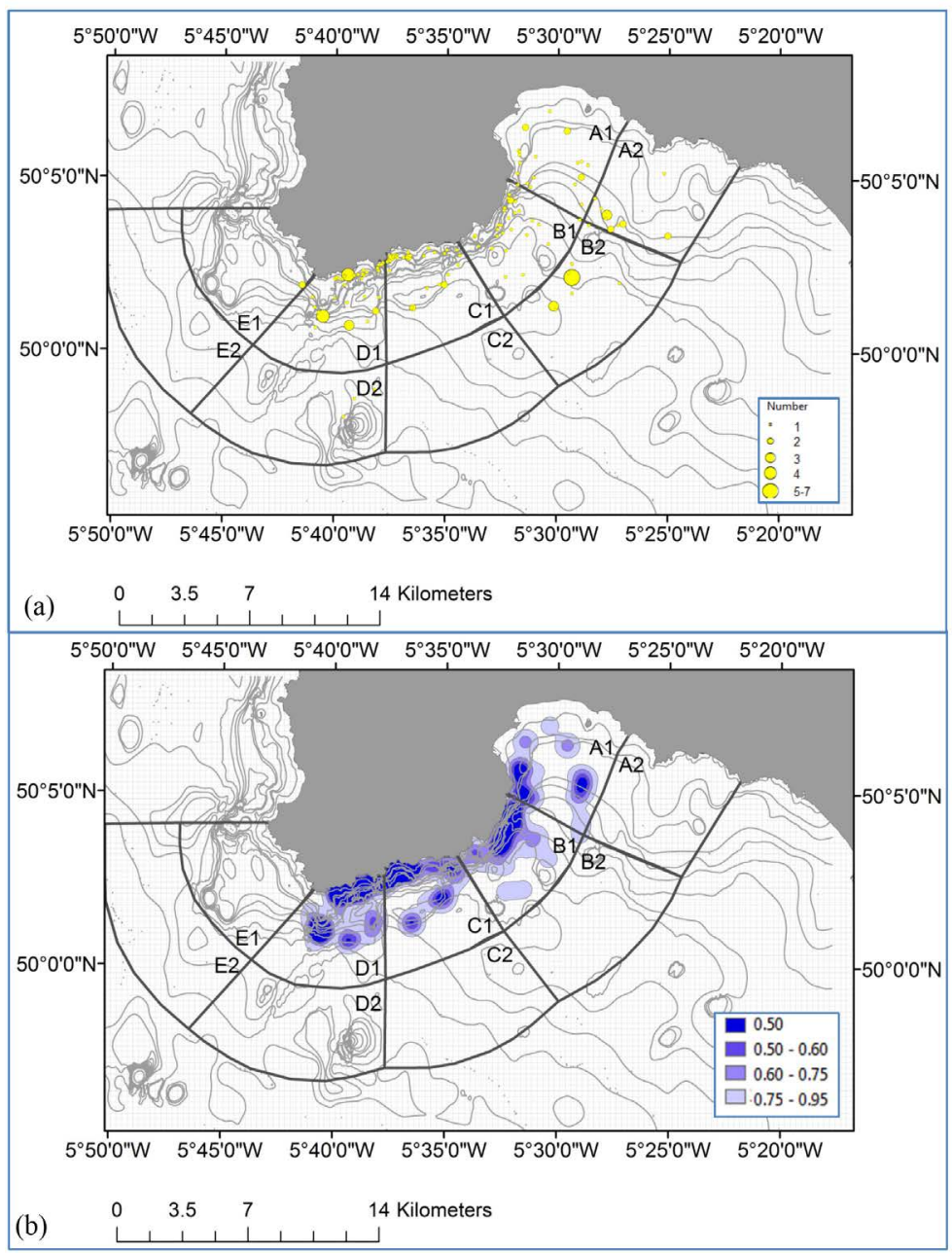

Figure 12. Sightings of basking shark (a) and kernel density utilisation grids plotted for inshore sectors (b). Densities are presented in percentiles $(50 \%$; $60 \% ; 75 \%$; $95 \%)$. Sighting locations are indicated by small circles relative to group-size.

\subsection{Other Species}

Leatherback turtles were recorded in July-August with a total of 11 sightings involving solitary animals (Figure 13). They were believed to be foraging based on their surfacing behaviour (repeated short dives of 5 minutes and generally remaining within the same area). One turtle was observed basking in an area with feeding porpoises and diving gannets. Another turtle was found foraging in vicinity of ocean sunfish.

One blue shark was recorded in July 2013, involving a relatively small shark (2 $\mathrm{m}$ length) which was nosing a floating glass bottle.

Minke whales were recorded on 17 occasions ( 9 adults and 12 juveniles) and were observed from May-September (Figure 6(b)). One adult and calf was recorded in late September whereas the remaining records involved either solitary adults or juveniles (mainly solitary or in pairs). Minke whales were mainly observed within sectors B1-E1 but also occasionally offshore (sectors C2-D2; 


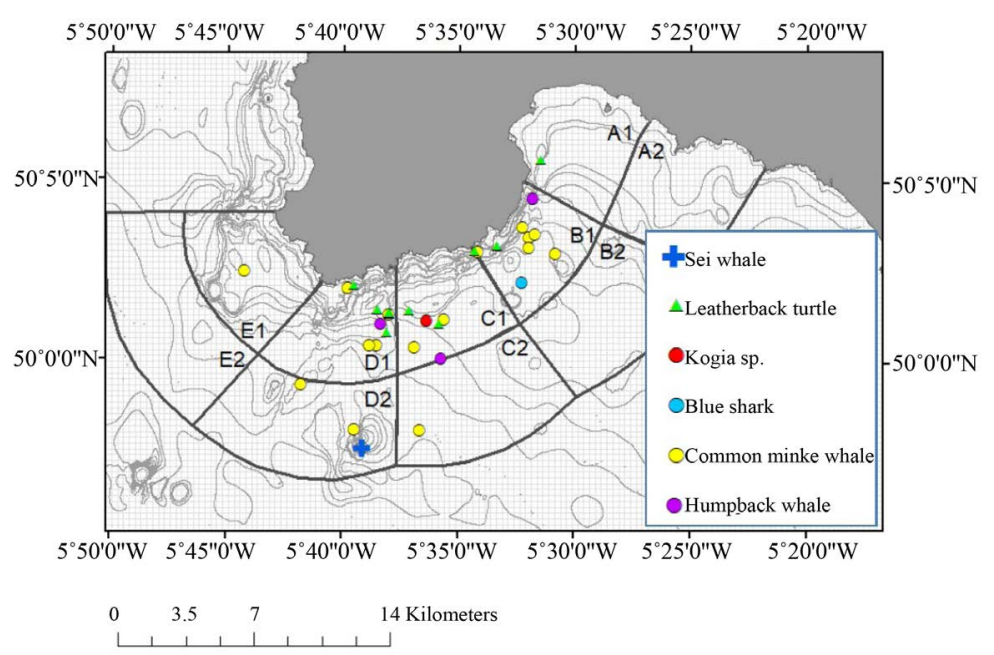

Figure 13. Sighting positions of leatherback turtle, common minke whale, Sei whale, humpback whale, Kogia sp. and blue shark.

Figure 13). The whales were either travelling (55.6\% of records) or feeding (44.4\%). Minke whales were more abundant in later years (2014-2015) and specifically in summer $\left(\chi^{2}=7.997, \mathrm{p}=0.018\right)$.

Large mysticetes were sighted in summer, including three solitary humpback whales (July-August) and one (probable) Sei whale in August (Figure 13).

During, the study period, after arriving back in Penzance Harbour on 11 October 2011, Marine Discovery staff were alerted to the presence of a small porpoise-sized cetacean swimming in Penzance harbour. Photographs later confirmed that the animal was a dwarf sperm whale (Kogia sima) a first record for UK waters (Figure 14). During dedicated surveys on 1 August 2014, another Kogia whale was sighted (sector C1; Figure 13). The animal was briefly seen logging and surfacing in close proximity to the vessel (30 m distance) before descending vertically (a typical surfacing behaviour of Kogia whales; [51]).

\section{Discussion}

Data collected from wildlife operators need to be interpreted with caution, for example an inherent problem with WTOs is the unavoidable interaction between vessel and animal [52]. For example underwater noise output from engines during the encounter spent in close proximity to animals and the number of vessels involved may result in behavioural responses or avoidance of high vessel impact areas [53]. It is therefore important when interpreting WTO data to consider information regarding the specific local legislation and vessel conditions [34]. The present data were collected using a relatively small platform, a 10 $\mathrm{m}$ long sailing catamaran which occasionally used $2 \times 20 \mathrm{hp}$ outboard engines. The operator had previously (2007-2010) used an ex-River Thames RIB (inboard $440 \mathrm{hp}$ diesel). Although, the RIB was able to cover a larger area, the sailing catamaran was more environmentally friendly (less fuel consumption) and had 


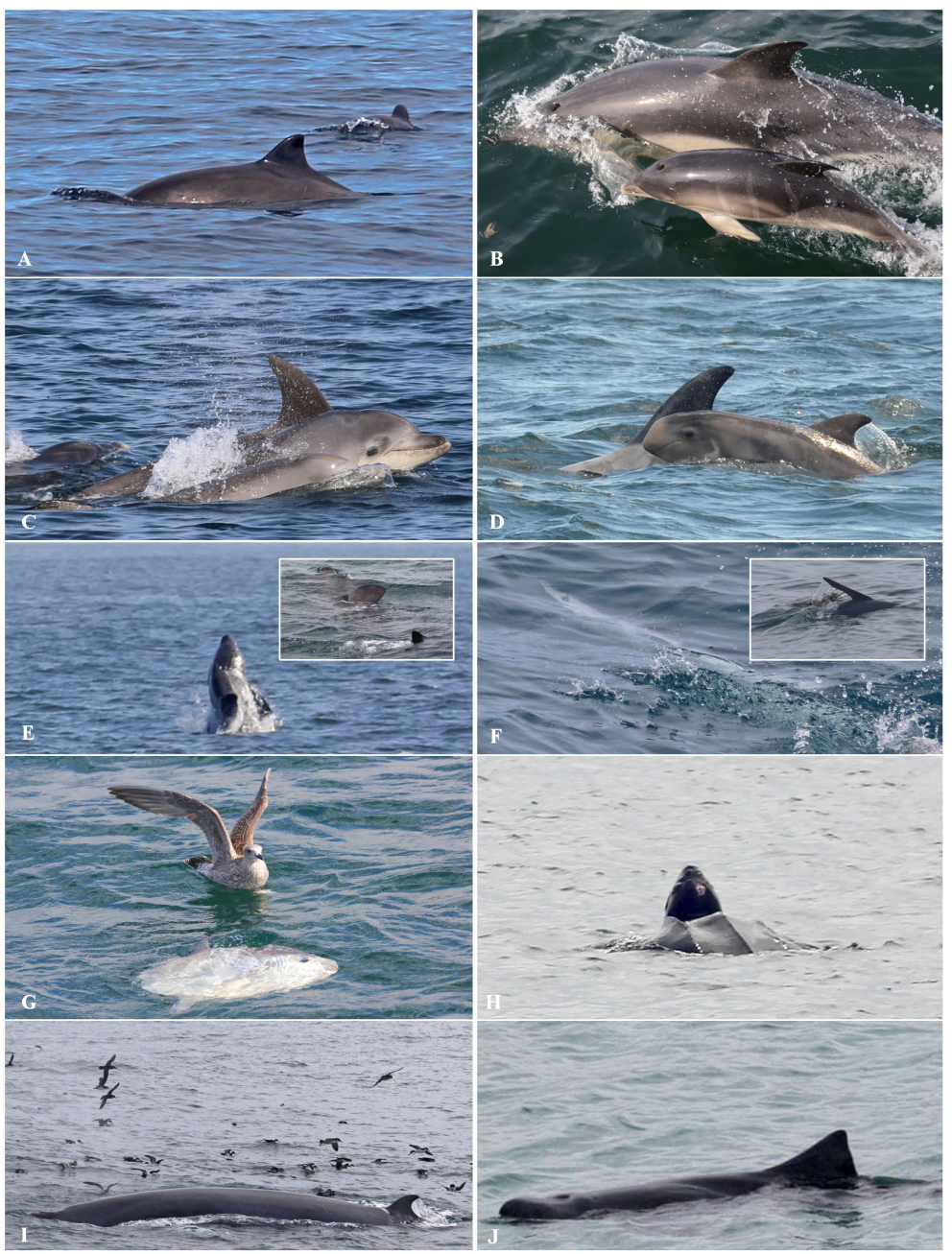

Figure 14. Photographs of the different marine megafauna species encountered during the survey period: Harbour porpoise (A); Common dolphin (B); Common bottlenose dolphin (C); Risso's dolphin (D); Basking shark (E); Blue shark (F); Ocean sunfish $(\mathrm{G})$; Leatherback turtle $(\mathrm{H})$, Northern minke whale (I); Dwarf sperm whale (J).

less underwater engine noise output. The data were collected from a WiSE accredited operator who abides by appropriate Codes of Conduct "developed to promote safe and sustainable watching of marine megafauna and focus on ways to help minimize any unintentional disturbance to wildlife" [54].

Our findings showed that the radial distance to which we can assume that the number of sightings remained constant could be determined from the detection curves. As expected the accumulation curves for small cetaceans (porpoises and common dolphins) differed to those for larger dolphins, consistent to findings with land-based data [24]. It was evident that for small cetaceans, the BSS0-3 followed a similar accumulation curve. Consistent to other studies, and in order to increase sample size, it was decided to pool BSS0-3 for small cetaceans [13] [14]. Previous studies have shown that higher sea states (BSS > 2) may significantly reduce the chances of sighting porpoises [24]. Indeed, the inflection 
points of BSS3 (based on perpendicular distance) were smaller for porpoises compared to those measured for BSS0-1, whilst this was not the case for larger species such as the Risso's dolphin (Table 3). The vessel often approached feeding gannets because cetaceans were likely to forage in association. Consequently the search effort increased after detecting such feeding aggregations. Only the latter part of our dataset includes information on whether foraging seabirds alerted the observer to the presence of cetaceans. By building up this type of information, it will be of interest to explore how this affected the detection curve for small cetaceans. Also group-size can influence the probability of detection (i.e. larger groups are often more easily detected) and this was indeed evident in the accumulation curves computed with a function of perpendicular distance against group-size (data not shown).

Overall, the relative smoothness of the accumulation curves showed that the present data are robust for future fine-scale habitat modeling studies. We recommend that studies like these will benefit from being able to select only those sightings with distances up to a certain inflection point for small cetaceans during different sea states or other variables [24].

\subsection{Harbour Porpoise (Phocoena phocoena)}

Porpoises were by far the most regularly encountered species and their relative abundance peaked in 2013 and 2015 with a sharp increase in numbers during late summer and early autumn. Similar results have been reported previously [17] although other studies reported numbers peaking in late winter and early spring [10] [16] [55]. The present study showed that $36.8 \%$ of all sightings involved $>5$ individuals and group-sizes occasionally reached up to $30-40$ individuals in autumn. Those areas with the highest abundance of porpoises were located $2-3 \mathrm{~km}$ from the coast with highest counts in B1. Although, further habitat studies are needed, it is evident from the bathymetric contours that the study area has relatively uneven bottom topographies and these together with localized tidal flow probably offer favourable feeding grounds [18].

Such localized hotspots also best explain our observations of temporary aggregations of larger groups of porpoises foraging in small areas, most dominantly in autumn. Occasional aggregations of larger groups $(10-20)$ have been reported elsewhere and specifically in connection with localised tidal flow [56] [57].

In UK waters, the main calving season is from March-August [58]. The percentages of new born calves peaked in Danish waters during July $(11.5 \%$ 23.8\%) and August (18.2\% - 23.5\%; [59]). In our study the percentages of calves, calculated as means across the years, were higher (July: 28.67\%, August: 29.53\%) with the majority of calves occurring $<2 \mathrm{~km}$ from the coast. Porpoise calves (Figure 14) were recorded within the Inner Mount's Bay area (A1) from August onwards and the highest ratios calf: adults were found within sectors B1-C1 during July-August. Our findings highlight that the wider Mount's Bay area is an important nursing area for porpoises. Although a number of SACs have been 
identified for which the harbour porpoise is listed for Natura, it has been difficult to clearly identify important sites for this species. Guidance from the European Commission (EC, 2000) stated that it is possible to identify areas that represent crucial factors for the life cycle of this species, using the following basis for site selection: (a) the continuous or regular presence of the species (although subjected to seasonal variations); (b) good population density (in relation to neighbouring areas); and (c) a high ratio of young to adults (in relation to neighbouring areas). A selection of five SACs in England and Wales and one SAC in Scotland have been identified as suitable areas for porpoise protection and these were recently submitted to the European Commission for approval [23] [60]. None of the proposed sites include the Western Approaches of the English Channel. They also do not reflect on ratios of young to adults as such data is often not available, especially not over larger spatial scales or longer periods. We recommend that effort-related WTO data can supply valuable information on the much needed ratios of young to adult porpoises.

\subsection{Short-Beaked Common Dolphin (Delphinus delphis)}

The common dolphin (Figure 14) occurred in large groups in April-November and was most abundant off Lamorna (sector B1). These dolphins occur yearround in the Western Approaches of the English Channel with the highest numbers reported in winter [13]. The seasonal distribution for common dolphins showed a significant pattern with the highest relative abundance recorded in autumn. This is consistent with findings for the Celtic Sea, Irish Sea and off the West Scottish coast where the abundance generally peak in autumn [64]. When comparing the sighting rates (number of schools per $100 \mathrm{~km}$ effort) this was found to be ten-fold lower (1.4 in autumn; this study) than reported during a winter study further offshore (10.9 [13]). A winter inshore movement of common dolphins using data collected from a PO (ferry) has been reported in the English Channel and Biscay, with a 5-fold increase (0.02 in 1996 to 0.11 in 2006) in wintertime occupancy in the western Channel [27].

Common dolphins become frequently by caught in fishing gear and their interactions with fisheries were monitored in the Western approaches in two subsequent winters [14]. A localised decline of dolphins in this winter hotspot has been apparent since 2007 [14] and is also reflected in the annual number and bycatch proportion of stranded common dolphins in southwest England during winter. These strandings increased in the late 1990s and peaked in 2004 and then gradually declined thereafter [65] [66]. This annual variation in numbers of common dolphins (evident in both strandings and effort-related boat surveys; [14] [16] [66]), together with direct mortality through bycatch and taking into account recent climate-driven range-shifts [27] [67] may best explain the decrease in common dolphin numbers in this area since 2005 [14]. Our data show that since 2011, the relative abundance of common dolphins has steadily been increasing in summer although a small dip in abundance was noted in 2014. 
Again, this is reflected in the UK stranding numbers of common dolphins which also showed an increase with more than twice the amount of strandings in 2011 compared to that of 2010 and remaining at comparable levels until 2014 [68] [69]. It will be of interest to explore this apparent increase further by understanding the fine-scale, albeit patchy distribution of these dolphins using future habitat modelling studies [70].

\subsection{Risso’s Dolphin (Grampus griseus)}

A marked increase in Risso's dolphin sightings occurred in 2015 with larger numbers occurring in spring and summer and especially within A1-B1. Prior to 2015, Risso's dolphins were occasionally recorded, similar to findings from previous studies [17] [55]. Fragments of cuttlefish (mantle with beak and arm mass eaten) were observed floating within the surrounding location of Risso's displaying foraging behaviour. In 2016, a dolphin was observed eating a cuttlefish at the surface (D. Jones, pers obs.). Risso's have been observed predating on octopus (Octopus vulgaris) off the Canary Islands in coastal waters $(<20 \mathrm{~m}$; [74]) and off Scotland they predominantly take lesser octopus (Eledone cirrhosa; [75]). Both the lesser octopus and cuttlefish remains were also found in the stomach of a Risso's dolphin stranded in southern England [76]. Cuttlefish typically spend the winter in deep water and move into shallow coastal waters to spawn from early spring to mid-summer, followed by mass adult mortality [77]. In late autumn, the juvenile cuttlefish migrate from inshore nursery grounds to deeper water in the western Channel and beyond [78]. The latter could explain the lack of Risso's sightings from late September onwards. Risso's dolphins utilize a large home range, with re-sightings of the same individuals moving from Welsh into Cornish waters [79].

The population size, based on the total number of (photo) identified individuals sighted over our study period, is estimated between 70 - 110 dolphins. Comparisons of photo-ID catalogues from other hotspots may add valuable information and add to our understanding of the wide-scale movements of Risso's throughout the region and possible connections between different parts of the meta-population. A total of 16 different calves were photographed during the survey period representing $14.5 \%$ of photographed individuals. This is slightly higher compared to a study in Wales [79]. The sheltered conditions of Mount's Bay may offer a preferred habitat where the risk for mother and calves (Figure 14) to become separated by fast flowing tides is much lower. Furthermore, it has been shown that dynamic features within relatively shallow coastal systems may enhance the foraging efficiency for Risso's by aggregating their prey in a predictable manner [24]. More research is needed to explore this at a fine-spatial scale within the Mount's Bay area.

\subsection{Common Bottlenose Dolphin (Tursiops truncatus)}

Bottlenose dolphins were the least encountered dolphin species. The core area of 
bottlenose dolphins overlapped with that of Risso's dolphins (A1-B1). They occurred mainly in small groups (Figure 14) that were travelling close inshore $(<1.5 \mathrm{~km}$ from the coast) which is in line with previous studies (2006-2009 [55], 2008-2009 [17]). A study focusing on incidental records reported by the public (1991-2008) showed that bottlenose dolphins were the most frequently sighted cetacean [18]. This is most likely due to their near-shore occurrence but also their long distance travels. A group of bottlenose dolphins was once tracked from Porthleven to Fowey for 7.5 hours during which the dolphins were estimated to have traveled just under 50 nmiles (De Boer, pers obs). Bottlenose dolphins also used a large home range with individuals moving from Cornish into Welsh waters [15].

Of interest is a sighting made at a distance of $5.5 \mathrm{~km}$ from the coast which involved at least 60 bottlenose dolphins, believed to be from the 'offshore stock'. The 'inshore' bottlenose dolphins $(<1.5 \mathrm{~km}$ from the coast) were typically traveling in much smaller groups (group-size 4 -16). Photographs revealed that inshore sightings involved the same individuals who appear to spend some time within the region and then to areas further afield [80]. Other studies also showed that inshore bottlenose dolphins can move extensively but remain close inshore within a rather narrow band [81]. It is unknown if the present inshore pods mix with the larger offshore pods. A study off Northwest Ireland reported on distinct inshore and offshore bottlenose dolphin communities [82]. With coastal ecosystems under increasing anthropogenic pressure, the inshore bottlenose dolphin communities face significant risks. The Mount's Bay area likely forms a key part of the home range of the inshore community of bottlenose dolphins [80]. We recommend that further research into habitat-use and the degree of interchange between inshore and offshore populations is needed in order to monitor and maintain the status of both inshore and offshore populations adequately.

\subsection{Ocean Sunfish (Mola mola)}

The ocean sunfish was typically encountered inshore and most specifically within region D1. The majority of sunfish were estimated to have a disc size $<60$ $\mathrm{cm}(83.7 \%)$ indicating they were young (adult sunfish reach up to $3-4 \mathrm{~m}$; [61]). Our observations are consistent with records from the western English Channel (off Plymouth) and from the Irish Sea where sunfish are $<1 \mathrm{~m} \mathrm{[3]} \mathrm{[6].} \mathrm{Sunfish}$ were present in May-October with the highest relative abundance measured for summer, a pattern which was also apparent in other studies [3] [6] [17] [21]. The study by [3] reported that sunfish were found annually in warmer inshore waters and productive fronts, presumably for foraging.

Of interest were the observations of great black-backed (Larus marinus) and herring gulls ( $L$. argentatus) associating with sunfish (2.4\% of all records; Figure 14). These gulls were pecking parasites from the sunfish which were basking on their sides [62]. Ocean sunfish were also occasionally observed breaching (13.4\% of all records) which may decrease parasite load [63]. Our observations support 
previous studies on sunfish being active in coastal, temperate seas during summer [3] [6]. It has also been suggested that the increased presence of smaller, young sunfish in coastal waters may be owing to local current regimes carrying them further inshore than adults [3]. Or represent a seasonal migration with individuals moving inshore from deep water overwintering sites to following the seasonal abundance of gelatinous prey [21] [61]. It will therefore be of interest to relate our sunfish records to the presence of the numerous compass jellyfish (Chrysaora hysoscella) and barrel jellyfish (Rhizostoma pulmo) which were also regularly recorded in the summer months.

\subsection{Basking Shark (Cetorhinus maximus)}

Basking sharks were most abundant in the western part of the study area close inshore (sectors C1-D1). The English Channel offers a suitable habitat for basking sharks throughout the year, but their presence is concentrated in the Western Channel [10]. Observations of basking sharks are highly seasonal throughout their range, with most sightings reported in coastal seas in summer [10] [71]. Previous surveys showed a peak number of sightings around May-June, with a drop as summer progressed to autumn [20]. Since 2005 however this trend seems to have been altered, with high inter-annual variability becoming evident and an overall trend towards a later influx of shark sightings in the region [72]. This matches our own observations of basking shark relative abundance peaking in summer, with a smaller peak in June and the highest peak in August. Our findings also confirmed a high level of variability between the survey years with numbers significantly peaking in 2013 but remaining low in later survey years (into 2016-2017; D. Jones, Pers Obs). A similar but earlier decline in sightings was recorded following a peak in 2007 from land-based observations carried out at Land's End [9].

Basking sharks when feeding may form loose aggregations when individuals feed on the same discrete patches of plankton [71] and this best explains that sharks were encountered either singly, in pairs or small groups (3 - 7, in August). Our observation on behaviour indicative of courtship matches records of social behaviour, so-called 'close-following', that has been recorded for sharks between 5 - $8 \mathrm{~m}$ length in southwest England [73]. We observed breaching sharks (Figure 14) in April $(\mathrm{n}=1)$, May $(\mathrm{n}=1)$, July $(\mathrm{n}=1)$ and August $(\mathrm{n}=2)$. Breaching is thought to be most prevalent during the proposed mating season in UK waters (May-June, [73]). The breaching of female sharks has been suggested to serve as a signal of receptivity to male sharks [73]. Other behaviours indicative of courtship (close approaches such as bumping or synchronised parallel swimming) were not observed during the present study.

\subsection{Other Species}

Minke whales were generally encountered solitary or in pairs and predominantly in B1. The whales were feeding in shallow waters and were often accompanied 
by shearwaters (Puffinus sp.; Figure 14) and diving gannets. Such associations are well known and have previously been reported involving minke whales and fin whales (Balaenoptera physalus) during winter and spring further West off the Scilly Isles [55]. There appears to be a general pattern of minke whales moving into coastal areas and particularly in late summer, but overall there is little knowledge regarding their offshore seasonal distribution [83] [84].

Three humpback whales and one probable Sei whale were observed in summer. Other baleen whales incidentally noted outside the survey period included bowhead whales (Balaena mysticetus) in May 2016 [85] and fin whales in August 2017 (D. Jones, pers obs).

Leatherback turtles (Figure 14) were encountered in summer (July-August; $n$ = 11) which match previous studies [86]. Records of leatherback turtles inferred from public sighting records also showed a seasonal pattern in their distribution, with numbers increasing during summer and declining during late autumn and winter [7]. The vast majority of leatherback turtles have been recorded in the Western Channel [10]. A steady increase in the number of live and dead leatherback turtle strandings has been noted in UK waters since 1970 [7]. This trend is likely to reflect increasing awareness for marine vertebrates, but may, in part, reflect an increasing number of this species in the North Atlantic [7]. As suggested by [8] it seems likely that this is a response to the changing distribution and abundance of gelatinous prey [87]. The turtles in the present study were believed to be foraging. Although, no direct association with jellyfish was visible at the surface, this has previously been reported off Cornwall [22].

To our knowledge no other Kogia whale sightings have been documented at sea off Cornwall. The whale was probably a dwarf sperm whale as the position of the dorsal fin appeared to be more centrally-placed rather than positioned posterior to the mid-point of the back as is the case for pygmy sperm whales (Kogia breviceps; [88]. Few sightings \& strandings of pygmy sperm whales have been reported in the Bay of Biscay and the English Channel [4] and recently, a pygmy sperm whale was found stranded on Angelsey (north Wales) in 2014 [89].

\subsection{Conclusions}

The western (English) Channel has been identified as a hotspot of biodiversity for megafauna [10]. It is therefore not surprising that the study area, which lies within this hotspot, holds a great diversity with twelve marine megafauna species recorded over the study period (excluding seals and seabirds). Particularly, the coastal waters showed the highest species richness, i.e. Inner Mount's Bay (A1), off Lamorna (B1) and the Runnelstone reef (D1). Equal survey coverage of the inshore waters was not achieved and this was mainly due to weather conditions and time constraints. Despite this potential bias, seasonal trends in occurrence were clear for several species. Density maps of marine megafauna indicated that while encounters may occur throughout the area and in all three seasons, the temporal distribution was significantly different with numbers peaking in autumn. 
Odontocetes were mostly recorded during autumn and less frequently during spring, whilst both sharks and ocean sunfish were more abundant during summer and least abundant during spring. Our data furthermore showed that the shallow coastal areas were particularly important as a nursing area for porpoises. Furthermore Risso's dolphins showed a high semi-residency pattern for adults accompanied by young calves mainly within one core habitat (Inner Mount's Bay). Although, data facilitated by WTOs have certain shortcomings (e.g. [34]), we highlight that the data collection protocols developed for this study secured efficient and precise data. We further recommend that collection protocols like this one could be made available to other WTOs and ultimately be implemented on a larger scale, requiring minimal investment [34] [90]. Ultimately, when pooling these data they can also be used to enhance management and research monitoring efforts and this is especially true for areas where long temporal baseline data are lacking and where funding for dedicated surveys is limited (e.g. [90]).

The spatial and seasonal distributions of the species documented here are most likely linked to dynamic oceanographic variables. For example, porpoises [18] [24] [39] [56] [57], Risso's dolphins [24], minke whales [37] [91], ocean sunfish [3], basking sharks [20] [71] and leatherback turtles [5] [7] have been reported in adjacent waters to associate with frontal zones, topographic and bathymetric features suggesting that these features play an important role in the fine-scale distribution of marine megafauna. We further recommend that the next step is to explore the underlying biological and physical processes that form this biodiversity at a fine spatial scale. Information on local habitat use by cetaceans often is carried out over relatively short durations (1 - 3 years; [17] [18]) and long temporal baseline data are critically needed for integration into meta-analyses that seek to elucidate important environmental forces and potential spatial conservation strategies [10].

\section{Acknowledgements}

Research has only been achieved by the efforts of Marine Discovery staff and their passengers. Special thanks go to Kimara McKrindle-Street, Tom Horton and James Saulino. Many thanks also to the anonymous reviewers who improved this manuscript.

\section{References}

[1] Sims, D.W., Southall, E.J., Richardson, A.J., Reid, P.C. and Metcalfe, J.D. (2003) Seasonal Movements and Behaviour of Basking Sharks from Archival Tagging: No Evidence of Winter Hibernation. Marine Ecology Progress Series, 248, 187-196. https://doi.org/10.3354/meps248187

[2] Hammond, P.S., Macleod, K., Berggren, P., Borchers, D.L., Burt, L., Canadas, A., et al. (2013) Cetacean Abundance and Distribution in European Atlantic Shelf Waters to Inform Conservation and Management. Biological Conservation, 164, 107-122. https://doi.org/10.1016/j.biocon.2013.04.010 
[3] Sims, D.W. and Southall, E.J. (2002) Occurrence of Ocean Sunfish, Mola mola Near Fronts in the Western English Channel. Journal of the Marine Biological Association of the United Kingdom, 82, 927-928. https://doi.org/10.1017/S0025315402006409

[4] Reid, J.B., Evans, P.G.H. and Northridge, S.P. (2003) Atlas of Cetacean Distribution in Northwest European Waters. Joint Nature Conservation Committee, Peterborough.

[5] Houghton, J.D.R., Doyle, T.K., Davenport, J. and Hays, G.C. (2006a) Jellyfish Aggregations and Leatherback Turtle Foraging Patterns in a Temperate Coastal Environment. Ecology, 87, 1967-1972.

https://doi.org/10.1890/0012-9658(2006)87[1967:JAALTF]2.0.CO;2

[6] Houghton, J.D.R., Doyle, T.K., Davenport, J. and Hays, G.C. (2006b) The Ocean Sunfish Mola mola: Insights into Distribution, Abundance and Behaviour in the Irish and Celtic Seas. Journal of the Marine Biological Association of the United Kingdom, 86, 1237-1243. https://doi.org/10.1017/S002531540601424X

[7] Witt, M.J., Broderick, A.C., Johns, D.J., Martin, C., Penrose, R., Hoogemoed, M.S. and Godley B.J. (2007) Prey Landscapes Help Identify Potential Foraging Habitats for Leatherback Turtles in the NE Atlantic. Marine Ecology Progress Series, 337, 231-243. https://doi.org/10.3354/meps337231

[8] Witt, M.J., Penrose, R. and Godley, B.J. (2007) Spatio-Temporal Patterns of Juvenile Marine Turtle Occurrence in Waters of the European Continental Shelf. Marine Biology, 151, 873-885. https://doi.org/10.1007/s00227-006-0532-9

[9] Jones, A.R. (2012) The Spatio-Temporal Distribution and Habitat Associations of Marine Mega-vertebrates off Southwest UK. Ph.D. Thesis, University of Southampton, Southampton.

[10] McClellan, C.M., Brereton, R., Dell'Amico, F., Johns, D.G., Cucknells, A.-C., Patrick, S.C., et al. (2014) Understanding the Distribution of Marine Megafauna in the English Channel Region: Identifying Key Habitats for Conservation within the $\mathrm{Bu}$ siest Seaway on Earth. PLoS ONE, 9, e89720. https://doi.org/10.1371/journal.pone.0089720

[11] Halpern, B.S., Walbridge, S., Selkoe, K.A., Kappel, C.V., Micheli, F., D’Agrosa, C., et al. (2008) A Global Map of Human Impact on Marine Ecosystems. Science, 319, 948-952. https://doi.org/10.1126/science.1149345

[12] Parsons, E.C.M., Bauer, A., McCafferty, D., Simmonds, M.P. and Wright, A.J. (2012) An Introduction to Marine Mammal Biology and Conservation. Jones \& Bartlett Publishing, Sudbury, MA.

[13] De Boer, M.N., Leaper, R., Keith, S. and Simmonds, M.P. (2008) Winter Abundance Estimates for Common Dolphin (Delphinus delphis) in the Western Approaches of the English Channel and the Effect of Responsive Movement. Journal of Marine Animals and their Environment, 1, 15-21.

[14] De Boer, M.N., Saulino, J.T., Leopold, M.F., Reijnders, P.J.H. and Simmonds, M.P. (2012) Interactions between Short-Beaked Common Solphin (Delphinus delphis) and the Winter Pelagic Pair-Trawl Fishery off Southwest England (UK). International Journal of Biodiversity and Conservation, 4, 481-499.

[15] Wood, C.J. (1998) Movement of Bottlenose Dolphins around the Southwest Coast of Britain. Journal of Zoology, 246, 155-163. https://doi.org/10.1111/j.1469-7998.1998.tb00144.x

[16] Pikesley, S.K., Witt, M.J., Hardy, T., Logerige, J., Williams, R. and Godley, B. (2011) 
Cetacean Sightings and Strandings: Evidence for Spatial and Temporal Trends? Journal of the Marine Biological Association of the United Kingdom, 92, 1809-1820. https://doi.org/10.1017/S0025315411000464

[17] Leeney, R.H., Witt, M., Broderick, A.C., Buchanan, J., Jarvis, D.S., Richardson, P.B. and Godley, B.J. (2012) Marine Megavertebrates of Cornwall and the Isle of Scilly: Relative Abundance and Distribution. Journal of the Marine Biological Association of the UK, 92, 1823-1833. https://doi.org/10.1017/S002531541100155X

[18] Jones, A.R., Wynn, R.B., Hosegood, P., De Boer, M.N., Butler-Cowdry, S. and Embling, C.B. (2014) Fine-Scale Hydrodynamics Influence the Spatio-Temporal Distribution of Harbour Porpoises at a Coastal Hotspot. Progress in Oceanography, 28, 30-48. https://doi.org/10.1016/j.pocean.2014.08.002

[19] Southall, E.J., Sims, D.W., Metcalfe, J.D., Doyle, J.I., Fanshawe, S., Lacey, C., et al. (2005) Spatial Distribution Patterns of Basking Sharks on the European Shelf: Preliminary Comparison of Satellite-Tag Geolocation, Survey and Public Sightings Data. Journal of the Marine Biological Association of the United Kingdom, 85, 1083-1088. https://doi.org/10.1017/S0025315405012129

[20] Witt, M.J., Hardy, T., Johnson, L., McClellan, C.M., Pikesley, S.K., Ranger, S., et al. (2012) Basking Sharks in the Northeast Atlantic: Spatio-Temporal Trends from Sightings in UK Waters. Marine Ecology Progress Series, 459, 121-134. https://doi.org/10.3354/meps09737

[21] Sims, D.W., Queiroz, N., Doyle, T.K., Houghton, J.D.R. and Hays, G.C. (2009) Satelite Tracking of the World's Largest Bony Fish, the Ocean Sunfish (Mola mola) in the North East Atlantic. Journal of Experimental Marine biology and Ecology, 370, 127-133. https://doi.org/10.1016/j.jembe.2008.12.011

[22] Penhallurick, R. (1990) Turtles of Cornwall, The Isles of Scilly and Devonshire. Dyllansow Pengwella.

[23] Joint Nature Conservation Committee (2017) Marine Conservation Zones. http://jncc.defra.gov.uk/page-4525

[24] De Boer, M.N., Simmonds, M.P., Reijnders, P.J.H. and Aarts, G.M. (2014) The Influence of Topographic and Dynamic Cyclic Variables on the Distribution of Small Cetaceans in a Shallow Coastal System. PLoS ONE, 9, e86331. https://doi.org/10.1371/journal.pone.0086331

[25] De Boer, M.N. (2013) Elusive Marine Mammals Explored-Charting Under-Recorded Areas to Study the Abundance and Distribution of Cetaceans using Multi-Method Approaches and Platforms of Opportunity. PhD-Thesis, Wageningen University, Wageningen, NL.

[26] Kiszka, J., Macleod, K., Van Canneyt, O., Walker, D. and Ridoux, V. (2007) Distribution, Encounter Rates, and Habitat Characteristics of Toothed Cetaceans in the Bay of Biscay and Adjacent Waters from Platform of Opportunity Data. ICES Journal of Marine Science, 64, 1033-1041. https://doi.org/10.1093/icesjms/fsm067

[27] MacLeod, C.D., Brereto, T. and Martin, C. (2008) Changes in the Occurrence of Common Dolphins, Striped Dolphins and Harbour Porpoises in the English Channel and Bay of Biscay. Journal of the Marine Biological Association of the United Kingdom, 89, 1059-1065. https://doi.org/10.1017/S0025315408002828

[28] Viddi, F.A., Hucke-Gaete, R., Torres-Florez, J.P. and Ribeiro, S. (2010) Spatial and Seasonal Variability in Cetacean Distribution in the Fjords of Northern Patagonian, Chile. ICES Journal of Marine Science, 67, 959-970.

https://doi.org/10.1093/icesjms/fsp288 
[29] López, A., Pierce, G.J., Valeiras, X., Santos, M.B. and Guerra, A. (2004) Distribution Patterns of Small Cetaceans in Galician Waters. Journal of the Marine Biological Association of the United Kingdom, 84, 283-294. https://doi.org/10.1017/S0025315404009166h

[30] Evans, P.G.H. and Hammond, P.S. (2004) Monitoring Cetaceans in European Waters. Mammal Review, 34, 131-156. https://doi.org/10.1046/j.0305-1838.2003.00027.x

[31] Simmonds, M.P., Rose, N. and De Boer, M.N. (2001) Whale-Watching and Critical Response Parameters. Document SC/53/WW1 submitted to the Scientific Committee of the International Whaling Commission, London, 23-27 July 2001, 1-16.

[32] International Whaling Commission (2002) Annex L: Report of the Sub-Committee on Whale-Watching. Report of the International Whaling Commission, 53, 2-3.

[33] De Boer, M. and Simmonds, M.P. (2002) An Introduction to the Web-Based Data Recording System for the Collection of Data from Whale-Watching Operations. Document SC/54/WW2, presented to the Scientific Committee of the International Whaling Commission, Shimonoseki, 2-24 May 2002, 1-15.

[34] Vinding, K., Bester, M., Kirkman, S.P., Chivell, W. and Elwen, S.H. (2015) The Use of Data from a Platform of Opportunity (Whale-watching) to Study Coastal Cetaceans on the Southwest Coast of South Africa. Tourism in Marine Environments, 11, 33-54. https://doi.org/10.3727/154427315X14398263718439

[35] Carlson, C., Kaufman, G., Ritter, F., Rodriguez-Fonseca, J., Robins, J., Rose, N., et al. (2016) Guiding Principles for Data Collection from Whale-watching Vessels as Platforms of Opportunity. Document SC/66b/WW/03, presented to the Scientific Committee of the International Whaling Commission, Bled, 4-20 June 2016, 3 p.

[36] Williams, R., Hedley, S.L. and Hammond, P.S. (2006) Modeling Distribution and Abundance of Antarctic Baleen Whales Using Ships of Opportunity. Ecology and Society, 11, 1-28. https://doi.org/10.5751/ES-01534-110101

[37] De Boer, M.N. (2010) Spring Distribution and Density of Minke Whale Balaenoptera acutorostrata along an Offshore Bank in the Central North Sea. Marine Ecology Progress Series, 408, 265-274. https://doi.org/10.3354/meps08598

[38] Ingram, S.N., Walshe, L., Johnston, D. and Rogan, E. (2007) Habitat Partitioning and the Influence of Benthic Topography and Oceanography on the Distribution of Fin and Minke Whales in the Bay of Fundy, Canada. Journal of the Marine Biological Association of the United Kingdom, 87, 149-156. https://doi.org/10.1017/S0025315407054884

[39] Isojunno, S., Matthiopoulos, J. and Evans, P.G.H. (2012) Harbour Porpoise Habitat Preferences: Robust Spatio-temporal Inferences from Opportunistic Data. Marine Ecology Progress Series, 448, 155-170. https://doi.org/10.3354/meps09415

[40] Currie, J.J., Stack, S.H., McCordic, J.A. and Kaufman, G.D. (2016) Whale and Dolphin Tracker: An Application for Data Collection on Platforms of Opportunity. Document SC/66b/WW/08, presented to the Scientific Committee of the International Whaling Commission, Bled, 4-20 June 2016, 1-3, 11 p.

[41] United Kingdom Hydrographic Office (1998) Admiralty Tidal Stream Atlas, the English Channel, Edition 5 (NP250). Admiralty Charts and Publications, The Hydrographic Office, Taunton.

[42] Stockin, K.A., Binedell, V., Wiseman, N., Brunton, D.H. and Orams, M.B. (2009) Behavior of Free-Ranging Common Dolphins (Delphinus sp.) in the Hauraki Gulf, New Zealand. Marine Mammal Science, 25, 283-301. https://doi.org/10.1111/j.1748-7692.2008.00262.x 
[43] Shane, S.H. (1990) Behavior and Ecology of the Bottlenose Dolphin at Sanibel Island, Florida. In: Leatherwood, S. and Reeves, R.R., Eds., The Bottlenose Dolphin, Academic Press, San Diego, 245-265. https://doi.org/10.1016/B978-0-12-440280-5.50016-0

[44] Channel Coastal Observatory (2008) Southwest Regional Coastal Monitoring Programme. https://www.channelcoast.org/

[45] General Bathymetric Chart of the Oceans (2014) Gridded Bathymetric Data. https://www.gebco.net/data_and_products/gridded_bathymetry_data/

[46] United Kingdom Hydrographic Office (2015) Standard Nautical Charts. https://www.admiralty.co.uk/charts/standard-nautical-charts

[47] Hope, A.C. (1968) A Simplified Monte Carlo Significance Test Procedure. Journal of the Royal Statistical Society, 30, 582-598.

[48] Clement, D.M. (2005) Distribution of Hector's Dolphin (Cephalorhynchus hectori) in Relation to Oceanographic Features. Ph.D. Thesis, University of Otago, Dunedin.

[49] Richardson, S.F., Stenson, G.B. and Hood, C. (2003) Growth of the Harbour Porpoise (Phocoena phocoena) in Eastern Newfoundland, Canada. NAMMCO Scientific Publications, 5, 211-221. https://doi.org/10.7557/3.2748

[50] Harvey-Clark, C.J., Stobo W.T., Helle, E. and Mattson, M. (1999) Putative Mating Behaviour in Basking Sharks off the Nova Scotia Coast. Copeia: American Society of Ichthyologists and Herpetologists, 3, 780-782.

[51] Baird, R.B. 2005. Sightings of Dwarf (Kogia sima) and Pygmy (K. breviceps) Sperm Whales from the Main Hawaiian Islands. Pacific Science, 59, 461-466. https://doi.org/10.1353/psc.2005.0031

[52] Parsons, E.C.M. (2012) The Negative Impacts of Whale-Watching. Journal of Marine Biology, 2012, 1-9. https://doi.org/10.1155/2012/807294

[53] Bejder, L., Samuels, A., Whitehead, H. and Gales, N. (2006) Interpreting Short-term Behavioural Responses to Disturbance within a Longitudinal Perspective. Animal Behaviour, 72, 1149-1158. https://doi.org/10.1016/j.anbehav.2006.04.003

[54] WiSe Scheme (2017) What Is WiSe. http://www.wisescheme.org/

[55] De Boer, M.N. and Saulino, J.T. (2009) Southwest England Cetacean Survey and Dead Dolphin Reports: 2006-2009. Whale and Dolphin Conservation Society, Chippenham.

[56] Pierpoint, C. (2008) Harbour Porpoise (Phocoena phocoena) Foraging Strategy at a High Energy Near-Shore Site in South-West Wales UK. Journal of the Marine Biological Association of the United Kingdom, 88, 1167-1173. https://doi.org/10.1017/S0025315408000507

[57] Goodwin, L. (2008) Diurnal and Tidal Variations in Habitat Use of the Harbour Porpoise (Phocoena phocoena) in Southwest Britain. Aquatic Mammals, 34, 44-53. https://doi.org/10.1578/AM.34.1.2008.44

[58] Murphy, S., Barber, J.L., Learmonth, J.A., Read, F.L., Deaville, R., Perkins, M.W., et al. (2015) Reproductive Failure in UK Harbour Porpoises Phocoena phocoena: Legacy of Pollutant Exposure? PLoS ONE, 10, e0131085. https://doi.org/10.1371/journal.pone.0131085

[59] Kinze, C.C. (1990) The Harbour Porpoise (Phocoena phocoena) Stock Identification and Migration Patterns in Danish and Adjacent Waters. Ph.D. Thesis, University of Copenhagen, Copenhagen.

[60] Scottish Natural Heritage (2017) The Use of Harbour Porpoise Sightings and 
Acoustic Data to Inform the Development of the Inner Hebrides and the Minches Draft Special Area of Conservation on the West Coast of Scotland. http://www.snh.gov.uk/docs/A1918277.pdf

[61] Fraser-Brunner, A. (1951) The Ocean Sunfishes (Family Molidae). Bulletin of the Natural History Museum, Zoology Series, 1, 87-121.

[62] Abe, T., Sekiguchi, K., Onishi, H., Muramatsu, K. and Kamito, T. (2012) Observations on a School of Ocean Sunfish and Evidence for a Symbiotic Cleaning Association with Albatrosses. Marine Biology, 159, 1173-1176. https://doi.org/10.1007/s00227-011-1873-6

[63] Konow, N., Fitzpatrick, R. and Barnett, A. (2006) Adult Emperor Angelfish (Pomacanthus imperator) Clean Giant Sunfishes (Mola mola) at Nusa Lembongan, Indonesia. Coral Reefs, 25, 208. https://doi.org/10.1007/s00338-006-0086-9

[64] Paxton, C.G.M., Scott-Hayward, L., Mackenzie, M., Rexstad, E. and Thomas, L. (2016) Revised Phase III Data Analysis of Joint Cetacean Protocol Data Resource (Report No. 517). JNCC, Peterborough.

[65] Jepson, P.D. (2005) Trends in Cetacean Strandings around the U.K. Coastline and Cetacean and Marine Turtle Post-mortem Investigations, 2000 to 2004 Inclusive (Contract CRO 238). Department for Environment, Food and Rural Affairs, Bristol.

[66] Deaville, R. and Jepson, P.D. (2011) UK Cetacean Strandings Investigation Programme. Final Report for the period $1^{\text {st }}$ January 2005-31 $1^{\text {st }}$ December 2010 (CR0346, CR0364.) Department for Environment, Food and Rural Affairs, Bristol.

[67] Lambert, E., MacLeod, C.D., Hall, K., Brereton, T., Dunn, T.E., Wall, D., Jepson, P.D., Deaville, R. and Pierce, G.J. (2011) Quantifying Likely Cetacean Range Shifts in Response to Global Climatic Change: Implications for Conservation Strategies in a Changing World. Endangered Species Research 15, 205-222. https://doi.org/10.3354/esr00376

[68] Murphy, S., Pinn, E. and Jepson, P. (2013) The Short-Beaked Common Dolphin (Delphinus delphis) in the North-eastern Atlantic: Distribution, Ecology, Management and Conservation Status. In: Hughes, R.N., Hughes, D.J. and Smith, I.P., Eds., Oceanography and Marine Biology: An Annual Review (Volume 51), CRC Press, Florida, 193-280.

[69] Deaville, R. (2015) UK Cetacean Strandings Investigation Programme, Final report for the period $1^{\text {st }}$ January 2005-31 $1^{\text {st }}$ December 2014 (MB0111). Department for Environment, Food and Rural Affairs, Bristol.

[70] Moura, A.E., Sillero, N. and Rodrigues, A. (2012) Common Dolphin (Delphinus delphis) Habitat Preferences Using Data from two Platforms of Opportunity. Acta Oecologica, 38, 24-32. https://doi.org/10.1016/j.actao.2011.08.006

[71] Sims, D.W. and Quayle, V.A. (1998) Selective Foraging Behaviour of Basking Sharks on Zooplankton in a Small-scale Front. Nature, 393, 460-464. https://doi.org/10.1038/30959

[72] Solandt, J.L. and Ricks, N. (2009) The Basking Shark Watch, 2009 Annual Report. Marine Conservation Society, Ross-on-Wye.

[73] Sims, D.W., Southall, E.J., Quayle, V.A. and Fox, A.M. (2000) Annual Social Behaviour of Basking Sharks Associated with Coastal Front Areas. Proceedings of the Royal Society of London. Series B, Biological sciences Royal Society (Great Britain), 267, 1897-1904.

[74] Ruiz, L., Neves, S., Martin, V., Perez-Gil, M., Tejedor M. and Perez-Gil, E. (2011) Risso's Dolphin Population Characteristics of Canary Islands with an Observation on Octopus Predation. Document presented at $25^{\text {th }}$ Conference of the European Cetacean Society, Cadiz, 21-23 March 2011, 219. 
[75] Santos, M.B., Pierce, G.J., Ross, H.M., Reid, R.J. and Wilson, B. (1994) Diets of Small Cetaceans from the Scottish Coast (C.M. 1994/N: 11). International Council for the Exploration of the Sea, Copenhagen.

[76] Clarke, M.R. and Pascoe, P.L. (1985) The Stomach Contents of a Risso's Dolphin (Grampus griseus) Stranded in Thurlestone, South Devon (UK). Journal of the Marine Biological Association of the United Kingdom, 65, 663-666. https://doi.org/10.1017/S0025315400052504

[77] Dunn, M.R. (1999) Aspects of the Stock Dynamics and Exploitation of Cuttlefish, Sepia officinalis (Linnaeus, 1758), in the English Channel. Fisheries Research, 40, 277-293. https://doi.org/10.1016/S0165-7836(98)00223-9

[78] Boucaud-Camou, E. and Boismery, J. (1991) The Migrations of the Cuttlefish (Sepia officinalis L.) in the English Channel. La Seiche: actes du Premier Symposium international sur La Seiche, Caen, 1-3 June 1989, 141-151.

[79] De Boer, M.N., Clark, J., Leopold, M.F., Simmonds, M.P. and Reijnders, P.J.H. (2013b) Photo-Identification Methods Reveal Seasonal and Long-Term Site-Fidelity of Risso's Dolphins (Grampus griseus) in Shallow Waters (Cardigan Bay, Wales). Open Journal of Marine Science, 3, 65-74.

[80] Brereton, T., Jones, D., Leeves, K., Lewis, K., Davies, R. and Russel, T. (2017) Population Structure, Mobility and Conservation of Common Bottlenose Dolphin off South-west England from Photo-Identification Studies. Journal of the Marine Biological Association of the United Kingdom, 2017, 1-9. https://doi.org/10.1017/S0025315417000121

[81] Defran, R.H., Weller, D.W., Kelly, D.L. and Espinosa, M.A. (1999) Range Characteristics of Pacific Coast Bottlenose Dolphins (Tursiops truncatus) in the Southern Californian Bight. Marine Mammal Science, 15, 381-393. https://doi.org/10.1111/j.1748-7692.1999.tb00808.x

[82] Oudejans, M.G., Visser, F., Englund, A., Rogan, E. and Ingram, S.N. (2015) Evidence for Distinct Coastal and Offshore Communities of Bottlenose Dolphins in the North East Atlantic. PLOS ONE, 10, e0122668. https://doi.org/10.1371/journal.pone.0122668

[83] MacLeod, C.D., Weir, C.R., Pierpoint, C. and Harland, E.J. (2007) The Habitat Preferences of Marine Mammals West of Scotland (UK). Journal of the Marine Biological Association of the United Kingdom, 87, 157-164. https://doi.org/10.1017/S0025315407055270

[84] Risch, D., Castellote, M., Clark, C.W., Davis, G.E., Dugan, P.J., Hodge, L.E.W., et al. (2014) Seasonal Migrations of North Atlantic Minke Whales: Novel Insights from Large-Scale Passive Acoustic Monitoring Networks. Movement Ecology, 2, 24. https://doi.org/10.1186/s40462-014-0024-3

[85] De Boer, M.N., Jones, D. and Jones, H. (2017) Ocean Wanderers: Extralimital Encounters with Bowhead Whales (Balaena mysticetus) in Temperate European Shallow Waters. Aquatic Mammals, 43, 279-288. https://doi.org/10.1578/AM.43.3.2017.279

[86] Godley, B.J., Gaywood, M.J., Law, R.J., McCarthy, C.J., McKenzie, C., Patterson, I.A.P., et al. (1998) Patterns of Marine Turtle Mortality in British Waters (1992-1996) with Reference to Tissue Contaminant Levels. Journal of the Marine Biological Association of the United Kingdom, 78, 973-984. https://doi.org/10.1017/S002531540004491X

[87] Mills, C.E. (2001) Jellyfish Blooms: Are Populations Increasing Globally in Response to Changing Ocean Conditions? Hydrobiologia, 451, 55-68. https://doi.org/10.1023/A:1011888006302 
[88] Willis, P.M. and Baird, R.W. (1998) Status of the Dwarf Sperm Whale (Kogia simus) in Canada. Canadian Field-Naturalist, 112, 114-125.

[89] Sea Watch Foundation. (2014) Rare Kogia Whale Live Strands! http://www.seawatchfoundation.org.uk/rare-kogia-whale-live-strands/

[90] Kaufman, G., Maldini, D., Ward, B., Merrill, P., Moore, B. and Kaufman, M. (2011) Enhancing Platforms of Opportunity Data Collection Using Newly Developed Whale \& Dolphin Tracking Software. Document SC/63/WW3 presented to the IWC Scientific Committee, Tromso, 30 May-11 June 2011, 1-12.

[91] Tetley, M.J., Mitchelson-Jacob, E.G. and Robinson, K.P. (2008) Summer Distribution of Coastal Minke Whales (Balaenoptera acutorostrata) in the Southern outer Moray Firth, NE Scotland, in Relation to Co-occurring Mesoscale Oceanographic Features. Remote Sensing of Environment, 112, 3449-3454.

https://doi.org/10.1016/j.rse.2007.10.015 